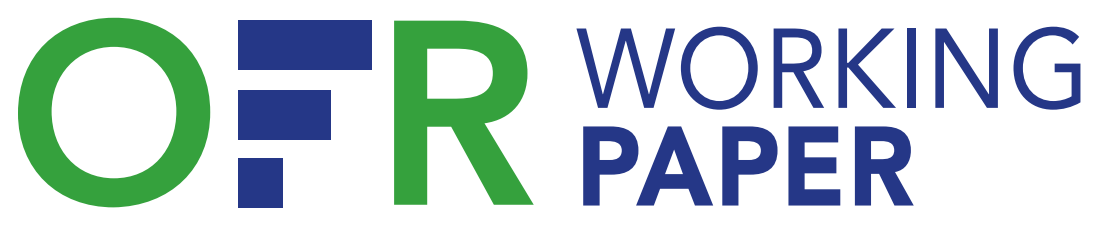

OFFICE OF FINANCIAL RESEARCH

19-03 | October 1, 2019

\title{
The Life of the Counterparty: Shock Propagation in Hedge Fund-Prime Broker Credit Networks
}

\author{
Mathias S. Kruttli \\ Board of Governors of the Federal Reserve System \\ Oxford-Man Institute of Quantitative Finance \\ mathias.s.kruttli@frb.gov
}

\section{Phillip J. Monin}

Office of Financial Research

phillip.monin@ofr.treasury.gov

\author{
Sumudu W. Watugala \\ Cornell University \\ Office of Financial Research \\ sumudu@cornell.edu
}

The Office of Financial Research (OFR) Working Paper Series allows members of the OFR staff and their coauthors to disseminate preliminary research findings in a format intended to generate discussion and critical comments. Papers in the OFR Working Paper Series are works in progress and subject to revision.

Views and opinions expressed are those of the authors and do not necessarily represent official positions or policy of the OFR or Treasury. Comments and suggestions for improvements are welcome and should be directed to the authors. OFR working papers may be quoted without additional permission. 


\title{
The Life of the Counterparty: Shock Propagation in Hedge Fund-Prime Broker Credit Networks*
}

\author{
Mathias S. Kruttli, Phillip J. Monin, and Sumudu W. Watugala ${ }^{\dagger}$
}

September 2019

\begin{abstract}
The collapse of Lehman Brothers illustrated the importance of managing prime broker counterparty risks for hedge funds. Liquidity shocks to prime brokers can lead to cycles of deleveraging that produce losses at funds and potentially have harmful effects on financial market function and credit provision. While the hedge fund-prime broker credit network is highly concentrated, the average hedge fund in our sample borrows from three prime brokers and has a total credit exposure of $\$ 2.15$ billion. We show that hedge fund borrowing tends to be overcollateralized and most of the collateral is allowed to be rehypothecated. Using a within fund-quarter empirical strategy, we identify the effects of an idiosyncratic liquidity shock to a major creditor. Such a shock results in significantly reduced borrowing due to the prime broker reducing credit supply instead of a precautionary reduction in credit demand from connected hedge funds. Borrowing by funds with more rehypothecable collateral is less affected because such collateral improves the constrained creditor's liquidity situation. Even large hedge funds simultaneously borrowing from multiple creditors see a significant reduction in their aggregate borrowing following the shock. Larger, more connected and better-performing hedge funds and those that do less OTC trading are better able to compensate for this loss.
\end{abstract}

JEL classification: G11, G23, G24, G01.

Keywords: Hedge funds, prime brokers, credit networks, rehypothecation, collateral.

${ }^{*}$ We thank Vikas Agarwal, Daniel Barth, Theodore Berg, Nina Boyarchenko, Gregory Feldberg, Nataliya Gerasimova, Sebastian Infante, David Johnson, Andrew Karolyi, Asim Khwaja, Dasol Kim, Nitish Kumar, Marco Macchiavelli, Matthew McCormick, Ralf Meisenzahl, David Ng, Cameron Peng, Lubomir Petrasek, Matthew Pritsker, Stacey Schreft, Chester Spatt, Stathis Tompaidis, Peyton Young, Lingling Zheng and seminar participants at Cornell University, Cambridge University, Federal Reserve Board of Governors, Office of Financial Research, 2018 LSE Paul Woolley Centre Conference, 2018 System Conference on Financial Intermediation, 2019 Paris Hedge Fund and Private Equity Research Conference, 2019 Dolomites Winter Finance Conference, 2019 Midwest Finance Association meeting, 2019 Chicago Financial Institutions Conference, 2019 Financial Intermediation Research Society Conference, and 2019 European Finance Association meeting for helpful comments. The analysis and conclusions set forth are those of the authors and do not indicate concurrence by the Board of Governors of the Federal Reserve System, its research staff, or the Office of Financial Research, U.S. Department of the Treasury. A previous draft of this paper was titled "Prime Broker Lending and Hedge Fund Exposures."

${ }^{\dagger}$ Kruttli: The Board of Governors of the Federal Reserve System and Oxford-Man Institute of Quantitative Finance. Email: mathias.s.kruttli@frb.gov. Monin: Office of Financial Research. Email: phillip.monin@ofr. treasury.gov. Watugala: Cornell University and Office of Financial Research. Email: sumudu@cornell.edu. 


\section{SCOPE OF RESEARCH}

The research and analysis conducted in this paper is in accordance with the mandate set

forth in the Dodd-Frank Wall Street Reform and Consumer Protection Act of 2010 that the Office of Financial Research study and monitor potential threats to financial stability and issues related to systemic risk in U.S. financial markets. 


\section{Introduction}

The hedge fund industry has grown from merely $\$ 291$ billion in assets under management in 2000 to over $\$ 3.1$ trillion in 2017. ${ }^{1}$ Because hedge funds often implement investment strategies that use leverage, the prime brokerage industry, which provides a large fraction of the leverage used by hedge funds, has also increased in size. Prime brokers face significant counterparty risks when lending to hedge funds (Lo, 2008; Duffie, 2010), as demonstrated during the Long-Term Capital Management crisis in 1998. Conversely, as the collapses of Bear Stearns and Lehman Brothers during the financial crisis of 2007-2009 showed, hedge funds are also exposed to counterparty risks from distress at their prime brokers. ${ }^{2}$

Anecdotal evidence suggests that hedge funds have diversified their prime broker exposures since the Lehman collapse, and recent regulatory changes, such as the Basel III reforms, are expected to influence how prime brokers allocate lending to hedge funds. ${ }^{3}$ Due to data limitations, however, it is unclear how post-crisis changes have affected hedge fund-prime broker credit dynamics. In this paper, we study the effects of prime broker distress on the provision of credit to hedge funds by constructing a novel dataset from regulatory filings that captures credit and collateral amounts between hedge funds and their major creditors at a quarterly frequency. ${ }^{4}$ Understanding these dynamics is crucial for assessing the financial stability implications of hedge funds and prime brokers. A liquidity shock to a prime broker can lead to the sudden reduction or withdrawal of funding to connected hedge funds, which in turn may result in forced liquidations of fund positions at steeply discounted prices (Ball, 2016b; Iyer and Macchiavelli, 2017). A prime broker liquidity shock can also motivate funds

\footnotetext{
${ }^{1}$ Estimates from BarclayHedge, https://www.barclayhedge.com/research/money_under_management. html (accessed August 28, 2019).

${ }^{2}$ For example, hedge funds that had Lehman as their prime broker were unable to access their rehypothecated collateral and faced severe funding constraints (Acharya, Philippon, Richardson, and Roubini, 2009; Aragon and Strahan, 2012; Ball, 2016a).

${ }^{3}$ See, for example, Kenny and Mallaburn (2017) and J.P. Morgan (2014).

${ }^{4}$ Beginning in 2012, large U.S. hedge funds are required to report their major counterparties and associated borrowing amounts on Form PF, which was adopted as part of the Dodd-Frank Wall Street Reform and Consumer Protection Act of 2010. Hedge funds report counterparties to whom the hedge fund owes $5 \%$ or more of its net asset value on Question 47 of Form PF: https://www.sec.gov/about/forms/formpf.pdf (accessed August 28, 2019).
} 
to withdraw their collateral assets by reducing leverage or selling out of positions, forcing the broker to return cash and collateral exactly when it needs liquidity most to fund its operations (Duffie, 2010). In stress periods these effects can contribute to impaired market functioning and reduced credit provision to firms and households. ${ }^{5}$

Our paper makes several contributions. First, we use a novel dataset to characterize the post-crisis hedge fund-prime broker network, illuminating the structure of the credit and counterparty exposures in this sector. Second, we empirically investigate the effects of a large liquidity shock to a prime broker on hedge fund lending and examine the effectiveness of hedge fund-prime broker diversification. Finally, we analyze which characteristics of a hedge fund and its collateral use make it more resilient to a prime broker shock.

We find that the hedge fund-prime broker credit network is characterized by a coreperiphery structure, similar to several other financial networks. ${ }^{6}$ The degree distribution of the network is highly skewed and a significant portion of the total credit is concentrated among $10 \%$ of the hedge funds and prime brokers. The average credit exposure between a hedge fund and a prime broker is $\$ 753.71$ million. The average hedge fund borrows at one time from close to three prime brokers. ${ }^{7}$ The prime brokers lending the most in this network exhibit a high degree of connectivity. While this enhances optimal risk-sharing and diversification, especially in tranquil times, such a structure can also destabilize a market by increasing the probability of contagion under certain conditions. ${ }^{8}$

Our data are at the hedge fund-creditor-quarter level, which allows us to analyze the effect

\footnotetext{
${ }^{5}$ Forced deleveraging can lead to cycles in which associated losses precipitate additional deleveraging. Price declines can also induce a contagion effect in which margin calls and forced selling occur at other funds or institutions holding similar assets. Market liquidity can dry up as funds rapidly switch from supplying liquidity to demanding it (Ben-David, Franzoni, and Moussawi, 2012; Jylhä, Rinne, and Suominen, 2014; Cotelioglu, Franzoni, and Plazzi, 2019). These effects can result in unstable and dislocated markets, and lead to inefficient allocations of capital. In an extreme case, such as during a financial crisis, hedge funds, prime brokers, and other institutional investors may significantly reduce or eliminate counterparty exposures, potentially leading to a dramatic reduction in credit provision.

${ }^{6}$ See, for example, Elliott, Golub, and Jackson (2014) and Farboodi (2014) on the structure of interbank lending markets and Munyan and Watugala (2019) on interdealer networks in corporate bond markets.

${ }^{7}$ There is variation across strategies: on average, event driven hedge funds only borrow from 1.5 prime brokers, while macro and relative value hedge funds borrow from more than 4 prime brokers.

${ }^{8}$ See Allen and Gale (2000); Eisenberg and Noe (2001); Acemoglu, Ozdaglar, and Tahbaz-Salehi (2015); Glasserman and Young (2015).
} 
on hedge funds from shocks to a creditor using a within fund-quarter empirical strategy adapted from Khwaja and Mian (2008), who use a similar framework to analyze lending between banks and firms. Using the set of hedge funds borrowing contemporaneously from both creditors that are suffering from a liquidity shock and those that are not, we are able to identify the effects of an idiosyncratic shock to a major creditor (a shock unrelated to its hedge fund lending business) on a particular hedge fund, while controlling for timevarying hedge fund characteristics using fund-quarter fixed effects. This allows us to examine whether the hedge funds' diversification of their prime broker exposures insulates them from a large liquidity shock to a major prime broker. We analyze the impact of the Deutsche Bank liquidity shock of 2015-2016 on the hedge fund lending market. Deutsche Bank is a major prime broker, and the uncertainty surrounding federal civil claims pursued by the US Department of Justice regarding Deutsche Bank's mortgage-backed securities business in 2006-2007 led to concerns about the financial health of the institution. ${ }^{9}$ This episode was marked by Deutsche Bank's credit default swap spread spiking at the end of 2015 and remaining at an elevated level far above its peers until the end of 2016 when Deutsche Bank and the US Department of Justice reached an agreement. ${ }^{10,11}$

Using this prime broker liquidity shock, we first analyze if the liquidity shock was passed on to hedge fund clients or if Deutsche Bank was able to cushion client borrowings against a reduction in funding. Our results confirm that hedge funds with a credit exposure to the shocked prime broker experienced large reductions in their borrowing of around 10\% per quarter from the fourth quarter of 2015 to the fourth quarter of 2016 . This result is robust to including fund-quarter fixed effects so that we compare the same hedge fund's credit growth from the shocked creditor relative to others it simultaneously borrows from, and thereby control for hedge fund borrowing demand shocks that are unrelated to the prime broker

\footnotetext{
${ }^{9}$ See the 2016 annual report of Deutsche Bank https://www.db.com/ir/en/annual-reports.htm (accessed August 28, 2019).

${ }^{10}$ A press release of the US Department of Justice regarding the settlement can be found here https://www. justice.gov/opa/pr/deutsche-bank-agrees-pay-72-billion-misleading-investors-its-sale-residential-mortgage-backed (accessed August 28, 2019).

${ }^{11}$ See the comparison of the time series of CDS spreads in Figure 2.
} 
liquidity shock. Next, we estimate if the decrease in hedge fund borrowing from the shocked prime broker was driven by the hedge funds' decision to borrow less from the constrained creditor, the hedge fund borrowing channel, or by constrained creditor's decision to lend less to hedge funds, the prime broker lending channel. We find evidence in line with the prime broker lending channel driving the reduction in credit. Finally, we analyze which hedge funds saw changes in their aggregate borrowing due to this shock, and find that the negative effect on total borrowing was largest for hedge funds that were smaller, were poorly performing, had borrowing relationships with fewer prime brokers, and had a large share of over-the-counter (OTC) trades. This result indicates that larger and better-performing hedge funds as well as hedge funds with more prime broker links and less OTC trading are better equipped to compensate for a shock to one of their prime brokers.

Our paper contributes to the literature on hedge fund leverage and prime brokerage by analyzing hedge fund-prime broker level credit data that allow us to directly identify the effect of a prime broker liquidity shock on hedge fund credit. Further, the hedge funds in our sample are large hedge funds that often do not report to commercial hedge fund databases but are particularly important for financial stability due to their size and interlinkages. Other papers in this growing literature find, for example, that negative shocks to prime broker stock prices increase the probability of hedge fund contagion (see, for example, Boyson, Stahel, and Stulz (2010)). Ang, Gorovyy, and van Inwegen (2011) analyze a subset of hedge funds connected to one fund-of-funds and find that the aggregate leverage of the hedge fund industry appears to be counter-cyclical compared to the leverage of listed investment banks and predictable by economy-wide factors such as funding costs and market values. Aragon and Strahan (2012) show that hedge funds that used Lehman Brothers as their prime broker experienced negative returns when Lehman Brothers collapsed in 2008. They hypothesize that this is likely because these funds could not access their rehypothecated collateral during the Lehman bankruptcy proceedings. This shock was associated with a decrease in the market liquidity of stocks traded by these hedge funds. Infante and Vardoulakis (2019) show 
theoretically how collateral runs can ensue when a broker is in distress. Eren (2015) develops a theoretical model to show that trading relationships between hedge funds and prime brokers can reflect specialization benefits. Chung and Kang (2016) and Gerasimova (2016) report that the return comovement of hedge funds that share the same prime broker is larger, and that the comovement is likely due to common information. ${ }^{12}$ Kumar, Mullally, Ray, and Tang (2017) provide evidence that hedge funds obtain early information from their prime brokers about corporate clients that obtain loans from the prime broker's investment bank. Barbon, Maggio, Franzoni, and Landier (2019) find that brokers leak information on fire sales to their best clients. Sinclair (2016) examines the capital introduction service provided by prime brokers to help hedge funds connect with investors and finds that prime brokers do indeed affect capital allocation in the hedge fund industry. Hedge fund prime brokerage has also increasingly come to the attention of policymakers concerned with the stability of financial markets (see, for example, King and Maier (2009) and Kenny and Mallaburn (2017)). Further, there are several papers that analyze how recent regulatory changes affect brokers' lending to market participants (see, for example, Boyarchenko, Eisenbach, Gupta, Shachar, and Van Tassel (2018) and Kotidis and van Horen (2018)).

This paper also contributes to the large literature on bank lending (see, for example, Khwaja and Mian (2008); Schnabl (2012); Chodorow-Reich (2013)). This literature often focuses on banks lending to firms. One aspect that is distinct in the setting in which prime brokers lend to hedge funds is the collateral that hedge funds post. Hedge funds usually post securities as collateral with the prime broker, and these securities can typically be rehypothecated by the prime broker. Because a hedge fund's access to these rehypothecated securities can be restricted if a prime broker is in bankruptcy, a hedge fund is likely more concerned about the counterparty risk that a prime broker poses compared to a firm that borrows from a bank. Moreover, we find that almost all hedge fund borrowing is secured and in fact, on average, the aggregate value of collateral posted by a hedge fund exceeds the

\footnotetext{
${ }^{12}$ Kahraman and Tookes (2019) show that common brokers can result in excess comovement of stocks during crisis periods.
} 
value of their total borrowing. As such, given that hedge fund borrowing is overcollateralized, losing access to their collateral, even temporarily, can be a significant concern for the liquidity position of a fund.

The remainder of the paper has the following structure. Section 2 presents the empirical design, including the identification strategy and data description. Section 3 describes the hedge fund-prime broker credit network. Section 4 presents the results of the main empirical analysis. Section 5 concludes.

\section{Empirical Design}

\subsection{Identification strategy}

We use an exogenous shock to a major prime broker that affects its liquidity condition to identify the extent to which idiosyncratic shocks are passed on to hedge fund borrowers and to examine the characteristics of a hedge fund that make it more resilient to such shocks. Figure 1 is a graphical representation of the empirical design of the main analysis. The figure depicts an example credit network with six nodes: three prime brokers (A, B, and C) and three hedge funds $(1,2$, and 3$)$. The amount of credit extended from prime broker $p$ to hedge fund $h, H_{-} F_{-} B_{-} C_{r e d i t}, p, t$, determines the strength of a link (edge) between two nodes.

We can identify the potential direct effects on lending to connected hedge funds $h=1$ and $h=2$ using a prime broker-hedge fund-time level differences-in-differences specification. The highlighted edges in Figure 1(b) are the treated edges and the edges in black are the controls. We use hedge funds that borrow from at least two prime brokers in the estimation, which allows us to identify the within fund effect: $H F_{-} P B_{-} C_{r e d i t}, A, t$ is treated, HF_PB_Credit ${ }_{1, B, t}$ is not; $H F_{-} P B_{-} C_{2} e d i t_{2, A, t}$ is treated, $H F_{-} P_{B}$ Credit $_{2, B, t}$ is not. All edges unconnected to the shocked creditor are also in the control set. We are able to include fund-time fixed effects in this setting, which absorbs all time-invariant fund-specific charac- 
teristics and time-varying fund characteristics, allowing for the identification of purely the impact of a lender shock by disentangling demand shocks at the fund-level.

In the firm-bank literature, analogous specifications have been used to identify bank supply effects (e.g., Khwaja and Mian (2008)). However, in the context of hedge fund-prime broker credit markets, we do not assume that the borrower is agnostic to who supplies its credit. Because hedge fund borrowing tends to be overcollaterized and a fund's access to its collateral can be restricted if a prime broker is in bankruptcy, a hedge fund is likely more concerned about the counterparty risk that a prime broker poses compared to a firm that borrows from a bank. As such, using fund-time fixed effects, while identifying the impact of the idiosyncratic creditor shock, does not distinguish between the borrower demand versus creditor supply channels. So we further analyze the differential impact of the prime broker shock on hedge funds that likely find it easier to switch their borrowing or likely improve the liquidity position of the prime broker (e.g., by having higher levels of rehypothecable collateral) to distinguish between the two channels.

After we establish the nature and extent of the direct impact on the credit extended from the shocked creditor, we examine aggregate effects to connected hedge funds. This allows us to analyze the characteristics of a hedge fund that make it more resilient to idiosyncratic lender shocks. Here, the highlighted nodes in Figure 1(c) are in the treated set. The funds unconnected to prime broker A are in the control set.

\subsection{Data}

The analysis in this paper uses Form PF and Form ADV filings of large hedge fund advisers who have at least US $\$ 1.5$ billion in regulatory assets under management across all their hedge funds and file Form PF on a quarterly basis. These advisers additionally file Section $2 \mathrm{~b}$ of Form PF, which carries further information on each of the adviser's "qualifying hedge funds" that have at least $\$ 500$ million in net asset value. ${ }^{13}$ We keep only qualifying hedge

\footnotetext{
${ }^{13}$ For a detailed description of the Form PF hedge fund data, see Flood, Monin, and Bandyopadhyay (2015) and Flood and Monin (2016).
} 
funds in our sample because our analysis requires data from the quarterly-filed section $2 \mathrm{~b}$. Our dataset includes hedge fund filings from 2012:Q4 to 2017:Q1.

There are 1,156 hedge funds, 489 hedge fund advisers, and 38 prime brokers in our baseline data sample, which is an unbalanced panel at the hedge fund-prime broker-quarter level. The sample construction, including merging the Form PF and Form ADV data, follows the methodology described in detail in Kruttli, Monin, and Watugala (2019). In addition to the variables used in that paper, which include net asset value $\left(N A V_{h, t}\right)$, portfolio illiquidity $\left(\right.$ PortIlliq $\left._{h, t}\right)$, share restrictions $\left(\right.$ ShareRes $\left._{h, t}\right)$, financing duration $\left(\right.$ FinDur $\left._{h, t}\right)$, manager's stake $\left(\right.$ MgrStake $\left._{h, t}\right)$, returns $\left(\right.$ HFReturn $\left._{h, t}\right)$, and flows $\left(H F F l o w s_{h, t}\right)$, there are several additional fields used for the empirical analyses in this paper. The primary analysis in the paper makes use of the amount of borrowing by a hedge fund from a prime broker (HF_PB_Credit ${ }_{h, p, t}$ ), which corresponds to the edges (connections) in the hedge fund-prime broker credit network.

\subsubsection{Constructing the hedge fund-prime broker credit network}

We obtain the list of prime brokers for each hedge fund from Form ADV. ${ }^{14}$ Information on a fund's exposure to its counterparties and creditors is captured by Form PF's Section 2b. The primary data on hedge fund borrowing exposures are in Question 47, which requires the fund to list all its significant creditors. ${ }^{15}$ Questions 22 and 23 list the five largest counterparties by aggregate exposure to and from the fund, respectively, while questions 36 and 37 capture the net collateral posted to or from these major counterparties. To construct a consistent hedge fund-creditor network through time, we manually inspect the "name" entries for questions 22, 23, and 47 in the Form PF filings and the prime broker fields in Form ADV filings and match these to parent institutions. Further details of the methodology used to process the

\footnotetext{
${ }^{14}$ Question 24 of Form ADV, Part 1A, Schedule D, Section 7.B.(1) collects data on the names and locations of a hedge fund's prime brokers and flags whether a prime broker also acts as a custodian for the fund.

${ }^{15}$ These are creditors to whom the hedge fund owes $5 \%$ or more of its NAV in a given quarter. This may include both institutions that are prime brokers of the hedge fund and those that are not. Table A.1 in Appendix A presents summary statistics on the coverage and classification of these creditors.
} 
data in these fields are included in Appendix A.

\subsubsection{Summary statistics}

Tables 1 and 2 present the summary statistics of the main variables used in our empirical analysis. Table 1, Panel A summarizes hedge fund characteristics. The $N$ column in the table reports the number of fund-quarter observations of each variable. Given the filing requirements of Forms $\mathrm{ADV}$ and $\mathrm{PF}$, our dataset is composed of large hedge funds with an average $N A V$ of $\$ 1.973$ billion and a median $N A V$ of $\$ 1.029$ billion. The PortIlliq variable is a measure of the expected weighted average time it would take for the orderly liquidation of a hedge fund's portfolio. The average PortIlliq is 35.521 days in our sample and the median is 12.615 days. Portfolio illiquidity exhibits a wide dispersion, with a standard deviation of 64.252 days. As shown in Kruttli, Monin, and Watugala (2019), there is a large variation in liquidity across hedge fund strategies. Similarly, ShareRes is a measure of the expected weighted average time it would take for a hedge fund's investors to withdraw the fund's equity. This variable gives a measure of the restrictions faced by a fund's investors, such as lock-up, redemption, and redemption notice periods. For our sample, the average ShareRes is 168.880 days (almost half a year) and the standard deviation is 110.844 days. FinDur measures the weighted average time to maturity of a fund's borrowing. On average, the financing duration is 43.395 days for our sample of hedge funds with a median of 3.5 days, indicating that most of the funds in our sample use short-term financing, if any. MgrStake captures the percentage of a hedge fund's equity that is owned by the fund's portfolio managers. It has a mean of $15.496 \%$ and a median of $6.00 \%$ in our sample.

During the time period covered by the data, 2012:Q4 to 2017:Q1, the hedge funds in our sample generated a mean quarterly return, HF Return, of $1.721 \%$ with a standard deviation of 5.402\%. The mean Fung and Hsieh (2004) seven factor risk-adjusted quarterly return, alpha, for the sample is $0.556 \%$ and the standard deviation is $2.218 \%$. The corresponding delevered measure, alpha_delev, constructed as in Kruttli, Monin, and Watugala (2019), has 
a mean of $0.358 \%$ and a lower standard deviation of $1.745 \%$. The mean quarterly investor net flow to a hedge fund, HFFlows, was negative during this period at $-0.481 \%$, with a standard deviation of $8.995 \%$.

SecOTCShare is the percentage of a fund's positions that are in over-the-counter (OTC) securities. ${ }^{16}$ Table 2 reports that these percentages can vary widely depending on a hedge fund's strategy. Equity funds have a smaller percentage of securities traded over-the-counter. In contrast, Credit, Macro, and Relative Value funds have a greater percentage of OTC trading for the securities in their portfolios, because these strategies tend to trade more OTC bonds and private equity compared to Equity funds.

The last three variables in Table 1, Panel A concern the hedge funds' prime broker relationships. The total amount borrowed by a hedge fund in a particular quarter from prime brokers, TotalH F Borrowing defined in equation (1), has a skewed distribution, with a mean of $\$ 2.147$ billion and a median of $\$ 472.701$ million. On average, a hedge fund in our sample has 2.862 prime brokers. The median NumPBsPerHF is 2. We measure the concentration of a hedge fund's credit exposure to its prime brokers with a Herfindahl-Hirschman Index, HFCreditor H HI, defined in equation (2).

$$
\begin{aligned}
& \text { TotalHFBorrowing }_{h, t}=\sum_{p} \text { HF_PB_Credit }{ }_{h, p, t},
\end{aligned}
$$

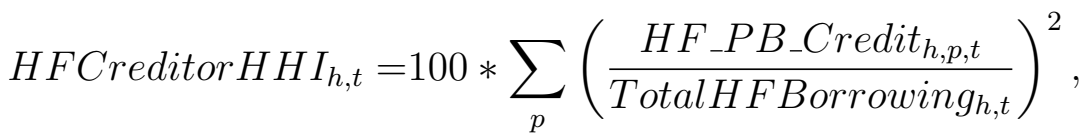

where $h$ refers to the hedge fund, $p$ to the prime broker, $t$ to the quarter, and HF_PB_Credit $t_{h, p, t}$ to the dollar amount borrowed by hedge $h$ from prime broker $p$ in quarter $t$. If a hedge fund has two prime brokers and its borrowing is split evenly between them, then its HFCreditor H HI would be 50 . The range of possible values for the measure is between $1 /$ (total number of prime brokers) and 100. The mean in our sample is 61.535 and the median is 52.818. Table 2 shows that on average, Macro funds have the highest number of prime brokers per fund with 4.202.

\footnotetext{
${ }^{16}$ From Question 24 of Form PF.
} 
Funds in this strategy are also the most diversified in terms of their borrowings as the mean HFCreditor H HI is 55.874 .

Table 1, Panel B summarizes the prime broker characteristics. By matching the publicly traded prime brokers in our sample to Morningstar data, we obtain their stock return and balance sheet information. During this period, these prime brokers had a mean quarterly return of $3.291 \%$ with a standard deviation of $12.804 \%$. The average stock market capitalization for the prime brokers is $\$ 74.957$ billion. The total amount lent by a particular prime broker in a particular quarter across all hedge funds, TotalPBLending defined in equation (3), has a a mean of $\$ 33.717$ billion and a median of $\$ 5.347$ billion. The number of hedge funds per prime broker, NumHFsPerPB, is similarly skewed with a mean of 44.729 and median of 10. The average share of all prime broker lending to hedge funds contributed by one prime broker, PBMktShare defined in equation (4), is $2.963 \%$ and the median is $0.466 \%$.

$$
\begin{aligned}
& \text { TotalPBLending }_{p, t}=\sum_{h} H F_{-} P B_{-} \text {Credit }_{h, p, t}, \\
& \text { PBMktShare }_{p, t}=\frac{\text { TotalPBLending }_{p, t}}{\sum_{p} \text { TotalPBLending }_{p, t}} \text {. }
\end{aligned}
$$

Table 1, Panel C presents statistics for the credit exposures between hedge funds and prime brokers through time. The variables summarized in this panel are at the hedge fundprime broker-quarter level. HF_PB_Credit ${ }_{h, p, t}$, the amount borrowed by hedge fund $h$ from prime broker $p$ at the end of quarter $t$, has an average of $\$ 753.812$ million and a median of $\$ 256.633$. The $90^{\text {th }}$ percentile for hedge fund-prime broker credit exposures is over $\$ 1.5$ billion. The variable $\frac{H F_{-} P B_{-} C r e d i t_{h, p, t}}{H F_{-} N A V_{h, t}}$ captures the size of the borrowing exposure to one prime broker relative to a fund's NAV. The mean value for this ratio is $34.422 \%$ and the standard deviation is $69.740 \%$. This indicates that the average amount borrowed from a prime broker in a given quarter is greater in size than a third of the fund's NAV. The

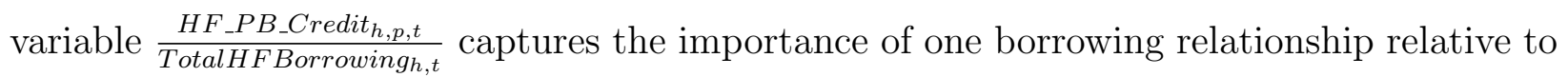


the total amount borrowed by a fund. On average, one borrowing relationship is $30.988 \%$ of the total borrowing by a fund. The PBRankInHF also shows the importance of a prime broker for a specific hedge funds, as each prime broker with a credit relationship to hedge fund $h$ is assigned a rank normalized to lie between 0 and 1 based on the amount lent. In contrast, from a prime broker's perspective, the importance of any one relationship is on average much smaller. The variable $\frac{H F_{-} P B_{-} \text {Credit }_{h, p, t}}{\text { TotalPBLending }_{p, t}}$ has a mean of $2.236 \%$ and a standard deviation of $8.406 \%$. The variable HFRankInPB, which assigns every hedge fund with a credit relationship to prime broker $p$ a rank normalized to lie between 0 and 1 based on the amount borrowed, also shows that for a prime broker the importance of a credit relationship is on average smaller.

\section{The hedge fund-prime broker credit network}

As described in the previous section, the data used in this study provide views of the hedge fund-prime broker credit network through time. This allows for the consideration of questions related to the resilience of the network to shocks and the implications for the diversification of counterparty exposures from the perspectives of both the hedge fund and the prime broker.

Several studies on a range of financial applications show that increased concentration can lead to increased aggregate volatility. ${ }^{17}$ The overall structure of a market or network of financial relationships affects its resilience to shocks and vulnerability to contagion. Existing studies examine the systemic risk that arises from the characteristics of a financial network such as the density of the network ${ }^{18}$, the degree distribution, node heterogeneity, and the distribution of risk across nodes (see, for example, Allen and Gale (2000); Eisenberg and Noe (2001); Acemoglu, Ozdaglar, and Tahbaz-Salehi (2015); Glasserman and Young (2015)). Acemoglu, Ozdaglar, and Tahbaz-Salehi (2015) and Glasserman and Young (2015) show

\footnotetext{
${ }^{17}$ See, for example, Gabaix (2011); Greenwood and Thesmar (2011); Acemoglu, Carvalho, Ozdaglar, and Tahbaz-Salehi (2012); Kruttli, Monin, and Watugala (2019).

${ }^{18}$ Network density is defined as the average number of connections (the average degree) of the nodes in the network divided by the maximum number of possible connections per node, i.e., average degree/(N-1), where $\mathrm{N}$ is the number of nodes in the network.
} 
that the extent of contagion and amplification within a financial network increases with the magnitude of the initial shock and the size and centrality of the starting node, in addition to the structure of the overall network. Papers such as Farboodi (2014) show that the nature of financial intermediation endogenously leads to core-periphery type network structures, with a highly skewed degree and centrality distribution.

Having a view of the overall network of lending relationships also allows us to account for the outside options of a borrower or lender, which determines whether and how much credit is received or given (Bala and Goyal, 1998; Jackson and Rogers, 2007; Acharya and Yorulmazer, 2008; Bloch and Dutta, 2009; Schwert, 2018). As we know the relative size or importance of a particular node within the credit network, and the number and strength of existing relationships between hedge funds and prime brokers, we can gain a better understanding of the relative bargaining power between the parties to a credit relationship and how the lending network may form and adjust (Bala and Goyal, 2000; Kranton and Minehart, 2001; Corominas-Bosch, 2004; Bloch and Jackson, 2007).

Figure 3 shows characteristics of the prime brokers in the network sorted into quintiles by a prime broker's total amount of lending across all hedge funds in a particular quarter, TotalPBLending $g_{p, t}$, with 5 being the set of prime brokers with the most lending and 1 being the set with the least. There are 38 prime brokers in our dataset and with an average of more than 33 lending to a hedge fund in any given quarter. Figure 3(a) shows that a prime broker in the highest TotalPBLending $g_{p, t}$ quintile on average has a lending exposure across all hedge funds of $\$ 119.877$ billion in a quarter, while prime brokers in quintile 3 have a mean TotalPBLending $g_{p, t}$ of $\$ 5.396$ billion. Figure 3(c) shows that the degree distribution is similarly highly skewed, with the prime brokers in quintile 5 on average lending to 155.787 hedge funds, compared to 13.504 hedge funds in quintile 3. In contrast, the average PBMktCap $p_{p, t}$ does not vary as significantly across TotalPBLending $g_{p, t}$ quintiles, and shows no monotonic trend.

Figure 4 shows characteristics of the hedge funds in the network sorted into deciles by 
a hedge fund's total amount of borrowing across all prime brokers in a particular quarter, TotalHFBorrowing,$t$, with 10 being the set of hedge funds with the most borrowing and 1 being the set with the least. There are 1,156 hedge funds in our dataset with an average of more than 529 funds borrowing from a prime broker each quarter. The mean TotalHF Borrowing $g_{h, t}$ in decile 10 is $\$ 14.637$ billion, compared to $\$ 0.884$ billion in decile 7 and $\$ 0.033$ billion in decile 1 . The hedge funds that borrow the most also tend to be the largest and the most levered. The hedge funds in decile 10 have an average $N A V_{h, t}$ of $\$ 6.558$ billion, compared to $\$ 1.862$ billion in decile 7 and $\$ 0.857$ billion in decile 3 . The average leverage ratio $\left(G A V_{h, t} / N A V_{h, t}\right)$ is over 5 for funds in decile 10 and 2 for decile 7 . Figure $4(\mathrm{~d})$ shows that the larger borrowers have the more liquid portfolios. The largest borrowers are also the most diversified in terms of their prime broker creditor base. $H F C r e d i t o r H H I_{h, t}$ is on average 31.810 for decile 10 and $N u m P B s P e r H F_{h, t}$ has a mean of 6.677. In contrast, hedge funds in decile 7 exhibit means of 52.826 and 2.898, respectively, for $H F C$ reditor $H H I_{h, t}$ and NumPBsPerHF $F_{h, t}$. We find that the hedge funds that borrow the most from their prime brokers dominate in terms of the amounts borrowed, are the largest in terms of NAV, are connected to the most number of prime brokers, and are relatively more diversified in terms of their creditor base. However, the average notional amount of credit between one prime broker and a hedge fund is much larger for funds in decile 10.

Figures 5 and 6 are depictions of the overall hedge fund-prime broker bipartite credit network. In both plots, the nodes in yellow depict 30 groups of hedge funds, grouped according to the total amount borrowed in that quarter (TotalHF Borrowing $g_{h, t}$ ). The nodes in red represent the top 20 prime brokers by TotalPBLending $g_{p, t}$, grouped into 10 groups of two. The depth of color of an edge indicates the amount of credit between the prime brokerhedge fund group pair connected by that edge. In Figure 6, the relative sizes of the vertices represent the total amount of credit extended or received by that node in that quarter.

These networks are highly concentrated, with a few players dominating the hedge fundprime broker lending market, as seen from the high level of skewness in the degree distri- 
bution of the network. The significant prime brokers in this network exhibit a high degree of connectivity, which is indicative of increased diversification or the potential to diversify credit counterparty exposures. This in turn can increase the extent of risk-sharing, especially in tranquil markets (Elliott, Golub, and Jackson, 2014; Acemoglu, Ozdaglar, and TahbazSalehi, 2015). However, high connectivity combined with a high degree of concentration can also increase the fragility of a financial network and lead to a higher potential for contagion (Allen and Gale, 2000; Acemoglu, Ozdaglar, and Tahbaz-Salehi, 2015; Glasserman and Young, 2015). In the main empirical analysis of the paper, we examine the consequences of a shock to central nodes in this network.

\section{Empirical Results}

\subsection{Prime broker shocks and lending allocation}

In Section 3, we document how the hedge fund-prime broker network is dominated by a few large prime brokers. This raises the question about how the borrowing of hedge funds is affected if a major prime broker experiences a liquidity shock. First, we determine if prime brokers pass onto hedge funds liquidity shocks that are unrelated to the prime brokerage business, or if they are able to shield borrowing hedge funds from these liquidity shocks.

The prime broker shock used in the subsequent analysis is the Deutsche Bank crisis of 2015/2016. In the fourth quarter of 2015, Deutsche Bank announced a record loss for the third quarter of 2015. ${ }^{19}$ The reported loss together with rumors about a large upcoming fine from the US Department of Justice due to malpractice in the mortgage backed securities business led to concerns about the solvency of Deutsche Bank. These concerns are reflected in the five-year senior debt credit default swap (CDS) spread shown in Figure 2. The CDS spread spiked in the fourth quarter of 2015, and remained far above the competitors' CDS

\footnotetext{
${ }^{19}$ The third quarter 2015 report of Deutsche Bank can be found here https://www.db.com/ir/en/ download/Deutsche_Bank_3Q2015_results.pdf (accessed August 28, 2019).
} 
spreads until December 2016, when Deutsche Bank and the Department of Justice reached an agreement which required Deutsche Bank to pay $\$ 7.2$ billion, a substantially lower amount than the initial fine of $\$ 14$ billion. ${ }^{20}$

This liquidity shock to Deutsche Bank is well suited to study how a shock to the liquidity of a bank can be passed on through their prime brokerage business to hedge funds. First, this shock was not caused by the Deutsche Bank's prime brokerage business and is therefore exogenous to hedge fund lending. Second, other prime brokers in our sample were largely unaffected by the Deutsche Bank crisis allowing us to exploit cross-prime-broker liquidity variation.

Our data allow us to estimate hedge fund-prime broker level panel regressions. We specify that changes over quarter $t$ in the log lending of prime broker $p$ to hedge fund $h$ are predicted by either of the following models:

$$
\begin{aligned}
& \Delta \log \text { HF_PB_Credit } \text { f }_{h, p, t}=\gamma P B S H O C K_{h, p, t}+\phi Z_{h, p, t-1}+\mu_{h}+\theta_{t}+\psi_{p}+\epsilon_{h, p, t}, \\
& \Delta \log H F \_P B \_C r e d i t_{h, p, t}=\gamma P B S H O C K_{h, p, t}+\nu_{h t}+\psi_{p}+\epsilon_{h, p, t},
\end{aligned}
$$

where $P B S H O C K_{h, p, t}$ is an indicator variable that takes the value one if hedge fund $h$ had borrowing exposure to the prime broker $p$ (Deutsche Bank) in quarter $t$ during the time period from the fourth quarter of 2015 to fourth quarter of 2016; $P B S H O C K_{h, p, t}$ is zero otherwise. In equation (5), we add hedge fund, prime broker, and hedge fund-prime broker level controls. We lag the controls to avoid endogeneity due to a simultaneity bias. Further, we include combinations of fund, strategy, prime broker, and quarter fixed effects. We also estimate the model with fund-quarter fixed effects shown in equation (6). The fund-quarter fixed effects are particularly important as they control for hedge fund-specific borrowing demand effects that are unrelated to the prime broker shock. Our sample includes only hedge

\footnotetext{
${ }^{20}$ The press release of the US Department of Justice can be found here https://www.justice.gov/opa/ $\mathrm{pr} /$ deutsche-bank-agrees-pay-72-billion-misleading-investors-its-sale-residential-mortgage-backed (accessed August 28, 2019).
} 
funds that have two or more prime broker connections and prime brokers with three or more hedge fund clients. If the shock to Deutsche Bank led to a decrease in borrowing of hedge funds from Deutsche, we would expect the estimate of $\gamma$ to be significant and negative. The standard errors are clustered at the prime broker-quarter level. The independent variables, with the exception of the PBSHOCK, are standardized.

The results are reported in Table 3 . The coefficient on $P B S H O C K$ is strongly significant and negative for all specifications. The magnitude of the coefficient estimate is economically significant, as the amount of borrowing of a hedge fund with exposure to the prime broker shock is predicted to decrease by more than $10 \%$ for each quarter of the shock exposure.

Of the control variables, the coefficient estimate of $H F R a n k \operatorname{InPB}$ is negative and strongly significant. This variable assigns each hedge fund with a credit relationship to a specific prime broker a rank normalized to lie between 0 and 1 based on the amount borrowed. The coefficient is negative and strongly significant, which indicates a mean reversion in credit growth. Similarly, the coefficient estimate of PRRankInHF is negative, although not significant for every specification, suggesting that hedge funds are predicted to borrow less from prime brokers to which they already have a large credit exposure. In line with this result, the coefficient estimate of HFCreditor HHI is positive and strongly significant, which is likely due to hedge funds with only one prime broker trying to expand their credit relationships to other prime brokers. Hedge fund flows and size are both strongly significant and positive, suggesting that large hedge funds and hedge funds with inflows are able to obtain more funding. Hedge funds are also predicted to borrow more from prime brokers that are their custodians.

Importantly, for the model with fund-quarter fixed effects, the $P B S H O C K$ variable is also strongly significant. Because the fund-quarter fixed effects account for hedge fund borrowing demand that is unrelated to the prime broker shock, this within hedge fund analysis emphasizes that hedge funds with exposure to the prime broker shock borrow less from Deutsche Bank compared to other prime brokers with which they also have a credit 
relationship. However, controlling for fund-quarter fixed effects is not sufficient to conclude that the prime broker lending channel, that is, the prime broker cutting lending to hedge funds as a result of the prime broker's liquidity shock, or the hedge fund borrowing channel, that is, the hedge fund reducing borrowing from the prime broker exposed to the liquidity shock, drive our findings. Unlike for firms, whose credit demand from a bank is often assumed to be independent of the bank's solvency (see, for example, Khwaja and Mian (2008)), hedge funds are known to be adversely affected by the collapse of their prime broker as the collateral is often rehypothecated and cannot be accessed in the event of a prime broker bankruptcy (see, for example, Aragon and Strahan (2012)). Therefore, further analysis is required to differentiate between the prime broker lending and the hedge fund borrowing channels.

To further investigate if the effect of the prime broker shock on hedge fund lending is due to the prime broker cutting back lending or the hedge fund reducing borrowing, we test if hedge funds for which switching their borrowing from one prime broker to another is likely less challenging had a larger reduction in lending from the constrained prime broker compared to hedge funds for which switching borrowing between prime brokers is likely more challenging. Further, we test whether the reduction in credit was less for hedge funds that improve the constrained prime broker's liquidity situation. We estimate the following panel data model with interaction terms:

$$
\begin{aligned}
\Delta \log H F_{-} P B_{-} \text {Credit }_{h, p, t}= & \gamma_{1} \text { PBSHOCK } K_{h, p, t}+\gamma_{2} \text { PBSHOCK } K_{h, p, t} \times X_{h, t-1} \\
& +\gamma_{3} X_{h, t-1}+\mu_{h}+\theta_{t}+\psi_{p}+\epsilon_{h, p, t},
\end{aligned}
$$

where $X_{h, t-1}$ is either the number of prime brokers, fund size, returns, share of OTC trading, the relative importance of prime broker $p$ for hedge fund $h$, and the fraction of rehypothecable collateral. We include a combination of fund, quarter, and prime broker fixed effects in the model. The standard errors are again clustered at the prime broker-quarter level, and the independent variables, other than the $P B S H O C K$ are standardized. We conjecture 
that hedge funds with credit links to several prime brokers and large or well-performing hedge funds can more easily switch borrowing between different prime brokers. In contrast, hedge funds for which the borrowing share from prime broker $p$ is high relative to their total borrowing likely find it more challenging to switch their borrowing to another prime broker. Therefore, if the variable $P B S H O C K$ predicts a decrease in lending because hedge funds reduce their borrowing from the prime broker as opposed to the prime broker cutting its hedge fund lending, we would expect the estimate of $\gamma_{2}$ to be significant and negative for the interaction with number of prime brokers, size, and returns. However, for the relative importance of prime broker $p$ we would expect the estimate of $\gamma_{2}$ to be significant and positive. From the prime broker's perspective, if the hedge fund uses higher levels of rehypothecable collateral, the prime broker is incentivized to cut less of its lending because such collateral improves the prime broker's liquidity situation. Finally, hedge funds with a higher share of OTC trading ${ }^{21}$ likely provide additional sources of revenue to the prime broker and such funds likely find it more difficult to switch their trading and related business to other prime brokers. As such, we would expect for the interactions with rehypothecable collateral share and OTC trading share, $\gamma_{2}$ to be significant and positive is the reduction in credit is due to the prime broker lending channel.

The estimates of the panel model given in equation (7) are reported in Table 4 . None of the coefficient estimates on the interaction terms are statistically significant with the exception of significant and positive coefficients for rehypothecable collateral share and OTC trading share. Therefore, hedge funds that could switch borrowing between prime brokers more easily generally do not seem to have a larger reduction in credit due to the prime broker shock. Moreover, hedge funds that improve the liquidity situation of the prime broker saw a smaller reduction in credit due to the prime broker shock. These results suggests that the decrease in borrowing due to the prime broker shock was likely driven by the prime broker lending channel and not the hedge fund borrowing channel.

\footnotetext{
${ }^{21}$ The prime broker services are likely more encompassing for hedge funds with a large OTC trading share.
} 
The results reported in Table 3 and Table 4 focus on the intensive margin of the hedge fund-prime broker credit relationship. To estimate the effect of the prime broker shock on the extensive margin, we estimate a panel model given by

$$
\Delta N u m H F s P e r P B_{p, t}=\gamma P B S H O C K_{p, t}+\phi W_{p, t-1}+\theta_{t}+\epsilon_{p, t},
$$

where the dependent variable is the change in the number of hedge funds with credit relationships to prime broker $p$, and $W_{p, t-1}$ are prime broker controls. The standard errors are clustered at the quarter level.

The results are reported in Table 5. The coefficient estimate of $P B S H O C K$ is highly significant and negative across all specifications, which shows that the prime broker shock not only led to reduced hedge fund borrowing from Deutsche Bank, but also led to credit ties between Deutsche Bank and hedge funds being cut.

\subsection{Hedge funds' resilience to lending shocks}

In Section 3, we show that hedge funds are on average simultaneously linked to multiple prime brokers through their credit relationships, which confirms anecdotal evidence that

hedge funds have diversified their prime brokerage exposure since the Lehman collapse of 2008 (see, for example, Kenny and Mallaburn (2017)) by borrowing from more than one prime broker. In this section, we analyze how the aggregate borrowing of hedge funds is affected if a major prime broker experiences a liquidity shock. In other words, we ask how effective the hedge funds' prime broker diversification is. We test if hedge funds are able to make up for the loss in funding from a distressed prime broker by borrowing more from other prime brokers. This analysis is important to assess the resilience of the hedge fund-prime broker network.

We estimate a panel regression model with the dependent variable being the change in 
quarter $t$ of the log of the total borrowing of hedge fund $h$. The model is given by

$$
\begin{aligned}
\Delta \log \text { TotalHF Borrowing }_{h, t}= & \gamma_{1} \text { ShockExposure }_{h, t-1}+\gamma_{2} \text { ShockExposure }_{h, t-1} \times X_{h, t-1} \\
& +\gamma_{3} X_{h, t-1}+\mu_{h}+\theta_{t-1}+\epsilon_{h, p, t}
\end{aligned}
$$

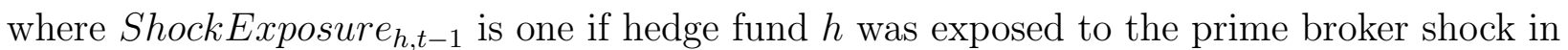
$t-1$, and is zero otherwise. For the first specification of the model we set $X_{h, t-1}$ to zero. To test if the ShockExposure had different effects on total hedge fund borrowing based on the ease with which hedge funds can switch prime brokers, $X_{h, t-1}$ is set to be either the number of prime brokers, fund size, returns, or OTC trading share of hedge fund $h$. As in the model given in equation (7), these variables act as a proxy for the ease with which hedge funds can move borrowing between prime brokers. While a large number of prime brokers, size, and returns should make it easier for hedge funds to find other prime brokers willing to lend to them, a large share of OTC trading likely has the opposite effect. Hedge funds that trade OTC need more services from their prime brokers and are less likely to switch prime brokers. When interacting the ShockExposure with these variables, we expect the estimate of $\gamma_{2}$ to be significant and positive when $X_{h, t-1}$ is the number of prime brokers, size, or returns, but negative when $X_{h, t-1}$ is the OTC trading share. We include fund and time fixed effects and cluster the standard errors by time. The independent variables other than the ShockExposure are standardized.

The results are given in Table 6. The coefficient on ShockExposure is significant and negative for all specifications indicating that on average, hedge funds with exposure to the prime broker shock could not completely compensate by borrowing more from other prime brokers. When interacting ShockExposure with the number of prime broker credit relationships of a hedge fund, the coefficient estimate is positive and strongly significant, which suggests that large hedge funds were able to compensate for the drop in borrowing due to the prime broker shock by borrowing more from other prime brokers. When interacting 
ShockExposure with the hedge fund size or the hedge fund return, the coefficient estimates are also significant and positive, in line with large and well performing hedge funds being able to move their borrowing more easily between prime brokers. For hedge funds with a large share of OTC trading, the coefficient is as expected negative and significant. This result suggests that hedge funds with a large share of OTC trading struggle to move their borrowing to other prime brokers. When including all the interaction terms in one regression, the coefficient estimates on the interaction terms remain strongly significant with the same sign.

The magnitude of the coefficients are economically significant as they are roughly of the same magnitude as the coefficient of the ShockExposure variable. This suggests that a one standard deviation move in the interaction variables can cancel out the effect of the prime broker liquidity shock.

\section{Conclusion}

We investigate the credit dynamics between prime brokers and hedge funds. Understanding how these financial institutions manage their counterparty exposures is important for academics and policymakers interested in whether the activities of prime brokers and hedge funds pose financial stability risks. Liquidity shocks to a prime broker can lead to forced deleveraging at connected hedge funds, with potentially destabilizing effects in markets where affected funds were active. Funds can also withdraw collateral from an affected prime broker, worsening the shock and reducing further the broker's capacity for credit provision. Such dynamics were thought to have occurred in the financial crisis of 2007-2009 with the collapses of Bear Stearns and Lehman Brothers but are hard to establish conclusively due to data limitations. We construct the hedge fund-prime broker credit network and trace out the effects of an idiosyncratic liquidity shock to a prime broker to its connected hedge funds.

For our analysis, we primarily use Form PF data, which provide us with hedge fund- 
prime broker level data on credit exposures. The hedge fund-prime broker credit network exhibits a core-periphery structure, with most of the total credit concentrated among $10 \%$ of the hedge funds and prime brokers in our sample. The average hedge fund borrows from up to three prime brokers in a given quarter. There is a high level of skewness in the degree distribution of the network. The significant prime brokers in this network exhibit a high degree of connectivity. A more dense network may help with optimal risk-sharing and diversification. However, such a structure may also be destabilizing, with a propensity for contagion depending on the characteristics of the more central nodes or the point of origination of a particular financial shock.

To understand whether a hedge fund's diversification of its prime broker exposures insulates it from a large liquidity shock to a major prime broker, we analyze the impact of the Deutsche Bank crisis of 2015/2016 on the hedge fund lending market. For connected funds, we estimate a reduction in borrowing from the shocked prime broker of up to $50 \%$ relative to controls. We further analyze for which hedge funds this shock led to changes in their aggregate borrowing, and find that the negative effect on total borrowing was largest for small or poorly performing hedge funds and hedge funds that only borrowed from a few prime brokers or engage in high levels of over-the-counter trading.

One aspect that is distinct in the setting where prime brokers lend to hedge funds compared to the standard firm-bank credit market setting is the collateral that hedge funds post. Hedge funds usually post securities as collateral with the prime broker, and these securities can be rehypothecated. A hedge fund's access to these rehypothecated securities can be restricted if a prime broker is in bankruptcy. Further, we find that almost all hedge fund borrowing is secured and in fact, on average, the aggregate value of collateral posted by a hedge fund exceeds the value of their total borrowing. As such, given that hedge fund borrowing is overcollateralized, losing access to their collateral, even temporarily, can materially impact the liquidity position of a fund. A hedge fund is likely more concerned about the counterparty risk that a prime broker poses than firms borrowing from commercial banks. 


\section{References}

Acemoglu, Daron, Vasco M Carvalho, Asuman Ozdaglar, and Alireza Tahbaz-Salehi, 2012, The network origins of aggregate fluctuations, Econometrica 80, 1977-2016.

Acemoglu, Daron, Asuman Ozdaglar, and Alireza Tahbaz-Salehi, 2015, Systemic risk and stability in financial networks, American Economic Review 105, 564-608.

Acharya, Viral V., Thomas Philippon, Matthew Richardson, and Nouriel Roubini, 2009, The financial crisis of 2007-2009: Causes and remedies, Financial Markets, Institutions 63 Instruments 18, 89-137.

Acharya, Viral V., and Tanju Yorulmazer, 2008, Information contagion and bank herding, Journal of Money, Credit and Banking 40, 215 - 231.

Allen, Franklin, and Douglas Gale, 2000, Financial contagion, Journal of Political Economy $108,1-33$.

Ang, Andrew, Sergiy Gorovyy, and Gregory B. van Inwegen, 2011, Hedge fund leverage, Journal of Financial Economics 102, 102-126.

Aragon, George O., and Philip E. Strahan, 2012, Hedge funds as liquidity providers: Evidence from the Lehman bankruptcy, Journal of Financial Economics 103, 570-587.

Bala, Venkatesh, and Sanjeev Goyal, 1998, Learning from neighbours, The Review of Economic Studies 65, 595 - 621.

— , 2000, A noncooperative model of network formation, Econometrica 68, 1181 - 1229.

Ball, Laurence, 2016a, The Fed and Lehman Brothers, Working Paper, NBER w22410.

— , 2016b, Supplementary document for "The Fed and Lehman Brothers", Working Paper, NBER w22410. 
Barbon, Andrea, Marco Di Maggio, Francesco Franzoni, and Augustin Landier, 2019, Brokers and order flow leakage: Evidence from fire sales, Journal of Finance forthcoming.

Ben-David, Itzhak, Francesco Franzoni, and Rabih Moussawi, 2012, Hedge Fund Stock Trading in the Financial Crisis of 2007-2009, The Review of Financial Studies 25, 1-54.

Bloch, Francis, and Bhaskar Dutta, 2009, Communication networks with endogenous link strength, Games and Economic Behavior 66, 39 - 56.

Bloch, Francis, and Matthew O. Jackson, 2007, The formation of networks with transfers among players, Journal of Economic Theory 133, 83 - 110.

Boyarchenko, Nina, Thomas M. Eisenbach, Pooja Gupta, Or Shachar, and Peter Van Tassel, 2018, Bank-intermediated arbitrage, Working paper.

Boyson, Nicole M., Christof W. Stahel, and Rene M. Stulz, 2010, Hedge fund contagion and liquidity shocks, Journal of Finance 65, 1789-1816.

Chodorow-Reich, Gabriel, 2013, The employment effects of credit market disruptions: Firmlevel evidence from the 2008-9 financial crisis, Quarterly Journal of Economics 129, 1-59.

Chung, Ji-Woong, and Byoung Uk Kang, 2016, Prime broker-level comovement in hedge fund returns: Information or contagion?, Review of Financial Studies 29, 3321-3353.

Corominas-Bosch, Margarida, 2004, Bargaining in a network of buyers and sellers, Journal of Economic Theory 115, $35-77$.

Cotelioglu, Efe, Francesco Franzoni, and Alberto Plazzi, 2019, What constrains liquidity provision? Evidence from hedge fund trades, CEPR Discussion Papers, No. 13645.

Duffie, Darrell, 2010, The failure mechanics of dealer banks, Journal of Economic Perspectives $24,51-72$. 
Eisenberg, Larry, and Thomas H. Noe, 2001, Systemic risk in financial systems, Management Science 47, $236-249$.

Elliott, Matthew, Benjamin Golub, and Matthew O. Jackson, 2014, Financial networks and contagion, American Economic Review 104, 3115 - 3153.

Eren, Egemen, 2015, Matching prime brokers and hedge funds, Working Paper.

Farboodi, Maryam, 2014, Intermediation and voluntary exposure to counterparty risk, Working Paper.

Flood, Mark D., and Phillip Monin, 2016, Form PF and the systemic risk of hedge funds: Risk-measurement precision for option portfolios, Journal of Alternative Investments 18, $125-147$.

— , and Lina Bandyopadhyay, 2015, Gauging Form PF: Data tolerances in regulatory reporting on hedge fund risk exposures, OFR Working Paper No. 15-13.

Fung, William, and David A. Hsieh, 2004, Hedge fund benchmarks: A risk-based approach, Financial Analysts Journal 60, 65-80.

Gabaix, Xavier, 2011, The granular origins of aggregate fluctuations, Econometrica 79, 733772.

Gerasimova, Nataliya, 2016, Do prime brokers induce similarities in hedge funds performance?, Working paper.

Glasserman, Paul, and H Peyton Young, 2015, How likely is contagion in financial networks?, Journal of Banking and Finance 50, 383 - 399.

Greenwood, Robin, and David Thesmar, 2011, Stock price fragility, Journal of Financial Economics 102, 471-490.

Infante, Sebastian, and Alexandros Vardoulakis, 2019, Collateral runs, Working paper. 
Iyer, Rajkamal, and Marco Macchiavelli, 2017, Primary dealers' behavior during the 2007-08 crisis: Part I, repo runs, FEDS Notes. Washington: Board of Governors of the Federal Reserve System.

Jackson, Matthew O., and Brian W. Rogers, 2007, Relating network structure to diffusion properties through stochastic dominance, The BE Journal of Theoretical Economics 7, $1935-1704$.

J.P. Morgan, 2014, Leveraging the leverage ratio - Basel III, leverage and the hedge fundprime broker relationship through 2014 and beyond, Investor Services.

Jylhä, Petri, Kalle Rinne, and Matti Suominen, 2014, Do hedge funds supply or demand liquidity?, Review of Finance 18, 1259-1298.

Kahraman, Bige, and Heather Tookes, 2019, Margin trading and excess comovement during crises, Working paper.

Kenny, Frank, and David Mallaburn, 2017, Hedge funds and their prime brokers: Developments since the financial crisis, Bank of England Quarterly Bulletin.

Khwaja, Asim, and Atif Mian, 2008, Tracing the impact of bank liquidity shocks: Evidence from an emerging market, American Economic Review 98, 1413-1442.

King, Michael R., and Philipp Maier, 2009, Hedge funds and financial stability: Regulating prime brokers will mitigate systemic risks, Journal of Financial Stability 5, 283-297.

Kotidis, Antonis, and Neeltje van Horen, 2018, Repo market functioning: The role of capital regulation, Working paper.

Kranton, Rachel E., and Deborah F. Minehart, 2001, A theory of buyer-seller networks, American Economic Review 91, 485 - 508. 
Kruttli, Mathias S., Phillip J. Monin, and Sumudu W. Watugala, 2019, Investor concentration, flows, and cash holdings: Evidence from hedge funds, OFR Working Paper No. $17-0 \%$

Kumar, Nitish, Kevin Mullally, Sugata Ray, and Yuehua Tang, 2017, Prime (information) brokerage, Working Paper.

Lo, Andrew W., 2008, Hedge funds, systemic risk, and the financial crisis of 2007-2008, Written Testimony for the House Oversight Committee Hearing on Hedge Funds.

Munyan, Benjamin, and Sumudu W. Watugala, 2019, What makes dealers central? Market dominance in credit interdealer networks, Working paper.

Schnabl, Philipp, 2012, The international transmission of bank liquidity shocks: Evidence from an emerging market, Journal of Finance 67, 897-932.

Schwert, Michael, 2018, Bank capital and lending relationships, Journal of Finance 73, 787830.

Sinclair, Andrew J., 2016, The allocative role of prime brokers, Working Paper. 


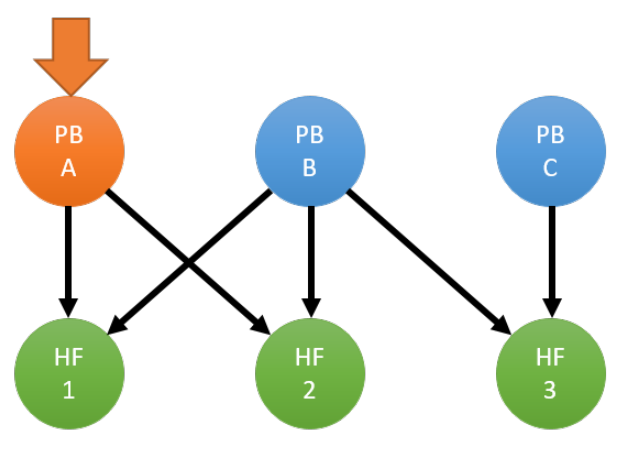

(a) Exogenous shock

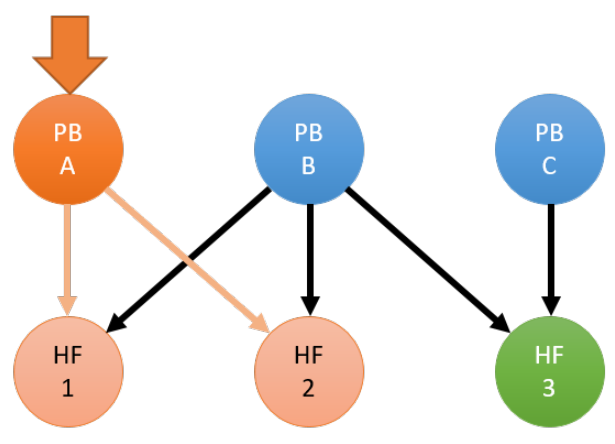

(c) Aggregate impact on connected funds

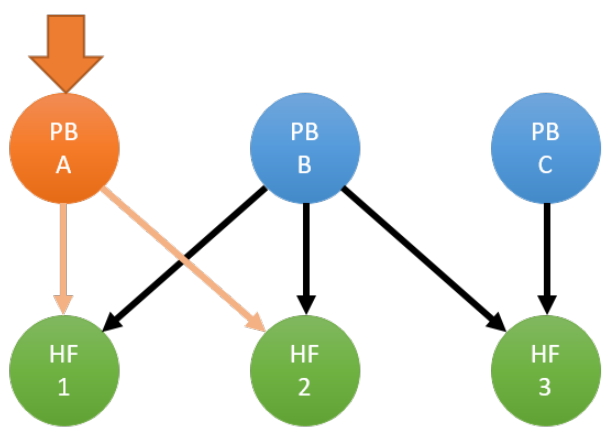

(b) Impact on lending

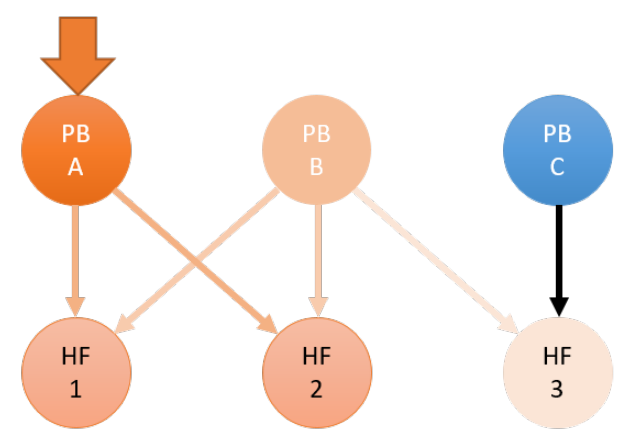

(d) Spillovers

\section{Figure 1: Empirical strategy using an exogenous shock to a major creditor}

This figure depicts an example credit network with six nodes: three prime brokers (A, B, and C) and three hedge funds $(1,2$, and 3$)$. The amount of lending from prime broker $p$ to hedge fund $h, H F \_P B \_C r e d i t_{h, p, t}$, determines the strength of a link (edge) between two nodes. (a) An exogenous shock to a major prime broker, $p=A$ affects liquidity condition of $A$. (b) Identify the potential direct effects on lending to connected hedge funds, $h=1$ and $h=2$, using a prime broker-hedge fund-time level differences-in-differences estimation. Identify the within fund effect: $H F_{-} P B_{-} C_{r e d i t}{ }_{1, A, t}$ is treated; HF_PB_Credit ${ }_{1, B, t}$ is not. $H F_{-} P B_{-} C r e d i t_{2, A, t}$ is treated; HF_PB_Credit ${ }_{2, B, t}$ is not. All unconnected edges are in the control set. (c) Analyze aggregate effects to connected hedge funds. Unconnected funds are in the control set. (d) Examine spillover effects to prime brokers and hedge funds unconnected in this market to the shocked creditor. 


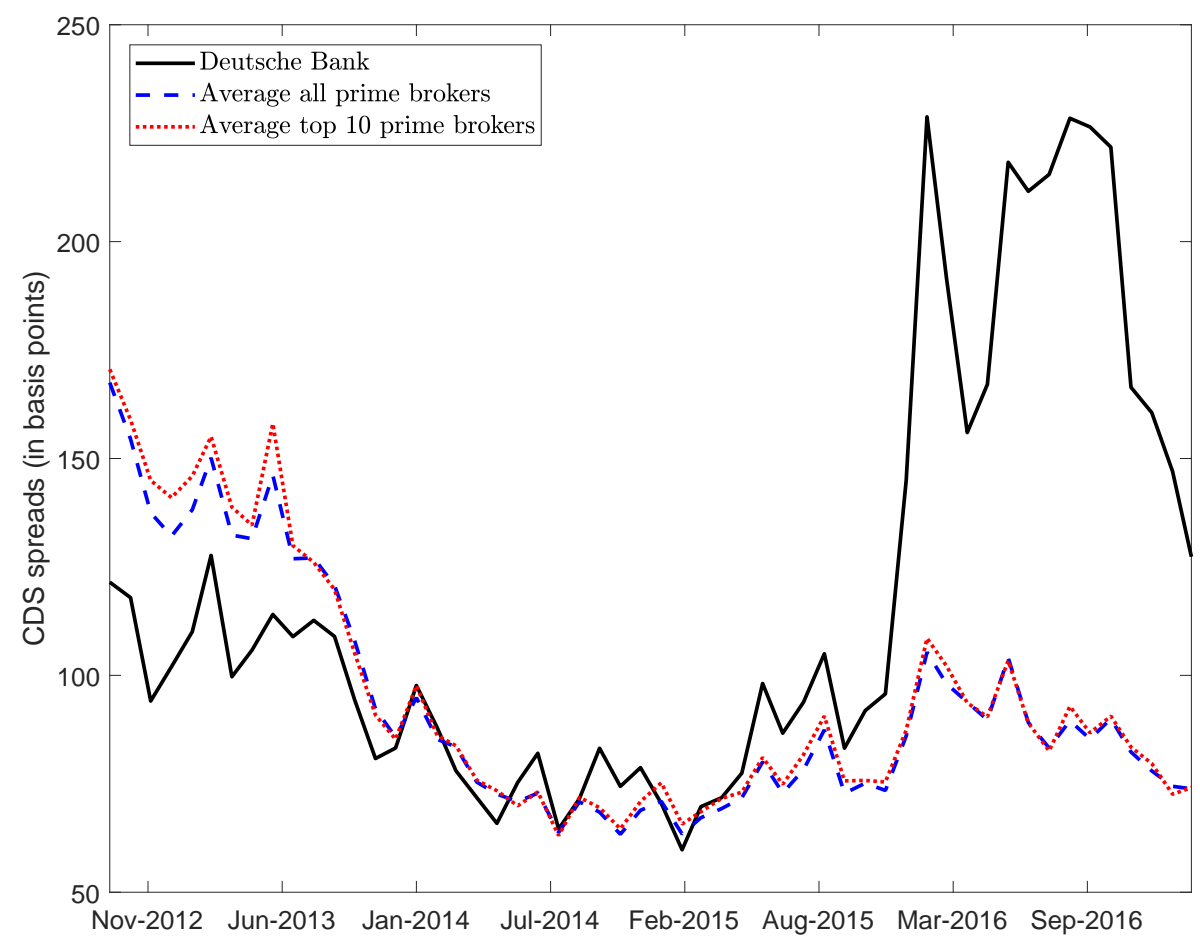

Figure 2: Five-year CDS spreads

This figure depicts the five-year senior debt CDS spread for Deutsche Bank, the average five-year senior debt CDS spread for all prime brokers and the largest ten prime brokers by average hedge fund lending. The averages exclude Deutsche Bank.

Source: Bloomberg 


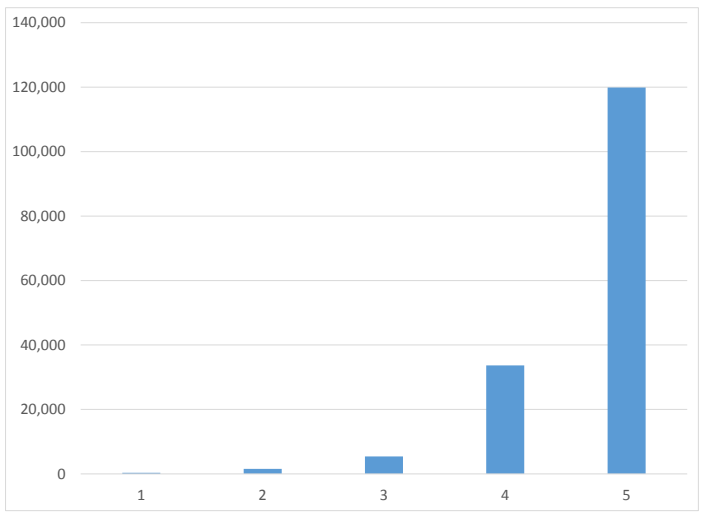

(a) TotalPBLending $g_{p, t}$ (US\$ millions)

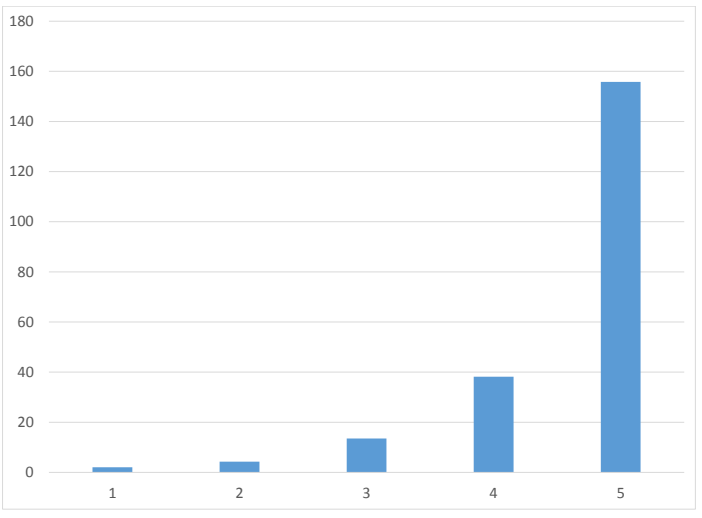

(c) NumHFsPerPB $B_{p, t}$

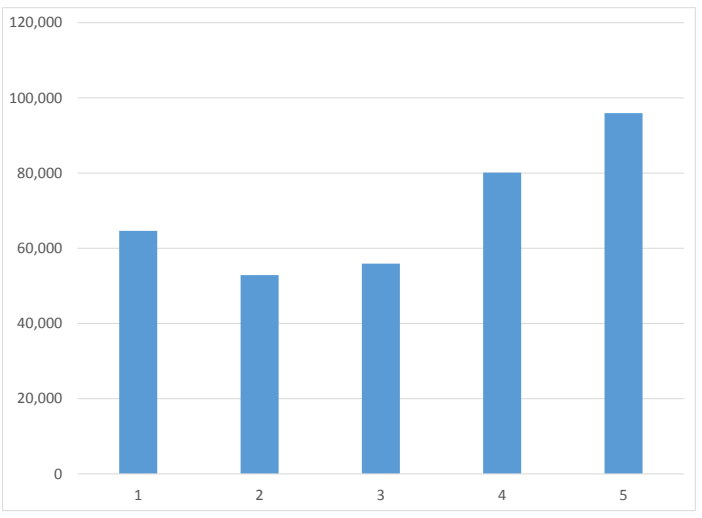

(b) PBMktCapp,t (US\$ millions)

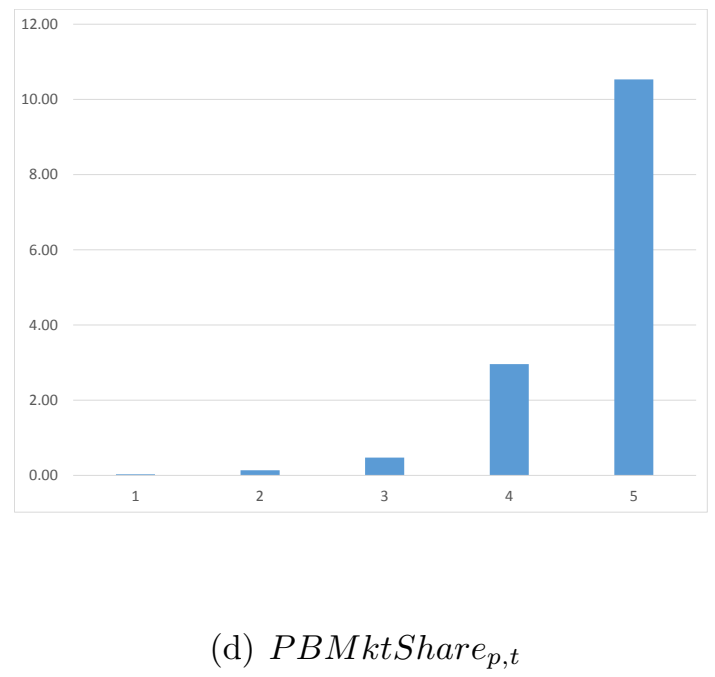

Figure 3: Prime broker characteristics by TotalPBLending ${ }_{p, t}$ quintile

This figure illustrates characteristics of the prime brokers sorted into TotalPBLending $p_{p, t}$ quintiles each quarter. The histograms show the mean value for all prime broker-quarter observations in that quintile for TotalPBLending,$t$, PBMktCapp,t, NumHFsPerPB $B_{p, t}$, and PBMktShare ${ }_{p, t}$, respectively. 

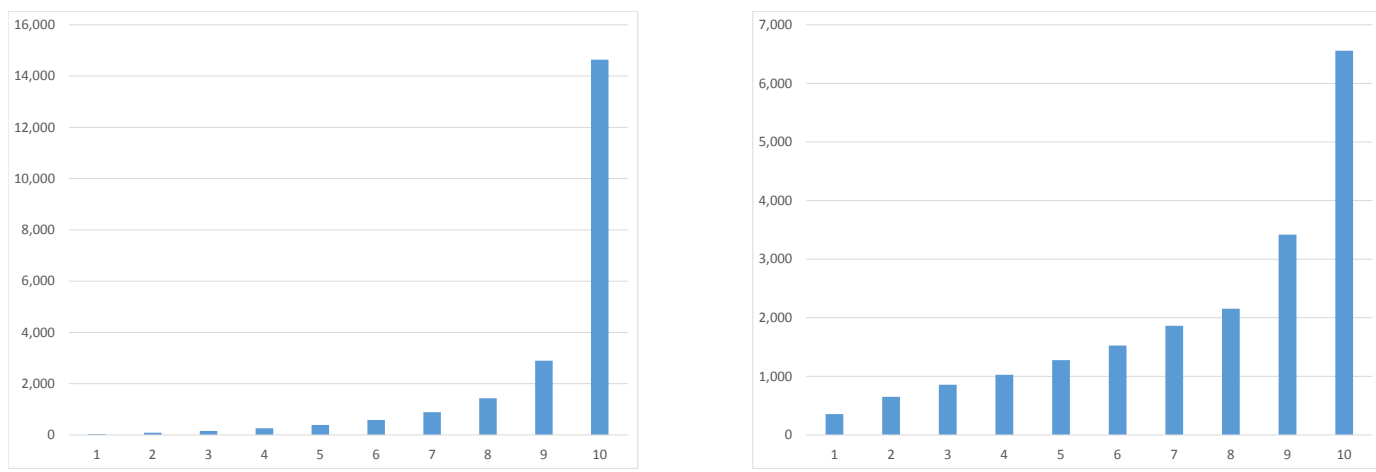

(a) TotalHFBorrowing , $_{, t}$ (US\$ millions)

(b) $N A V_{h, t}$ (US\$ millions)
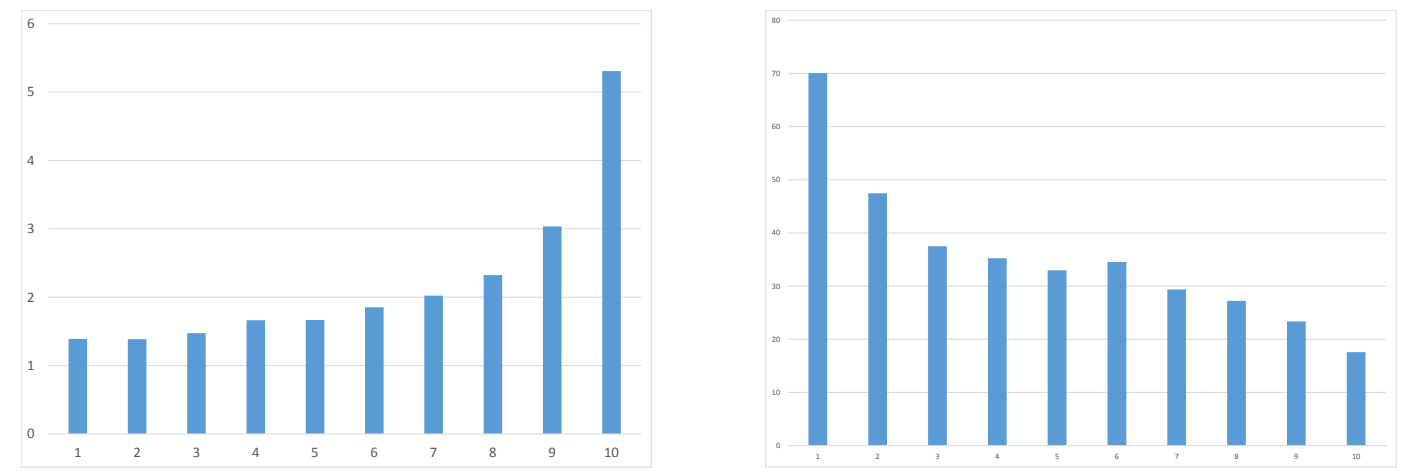

(c) Leverage $h, t$

(d) PortIlliq P,t
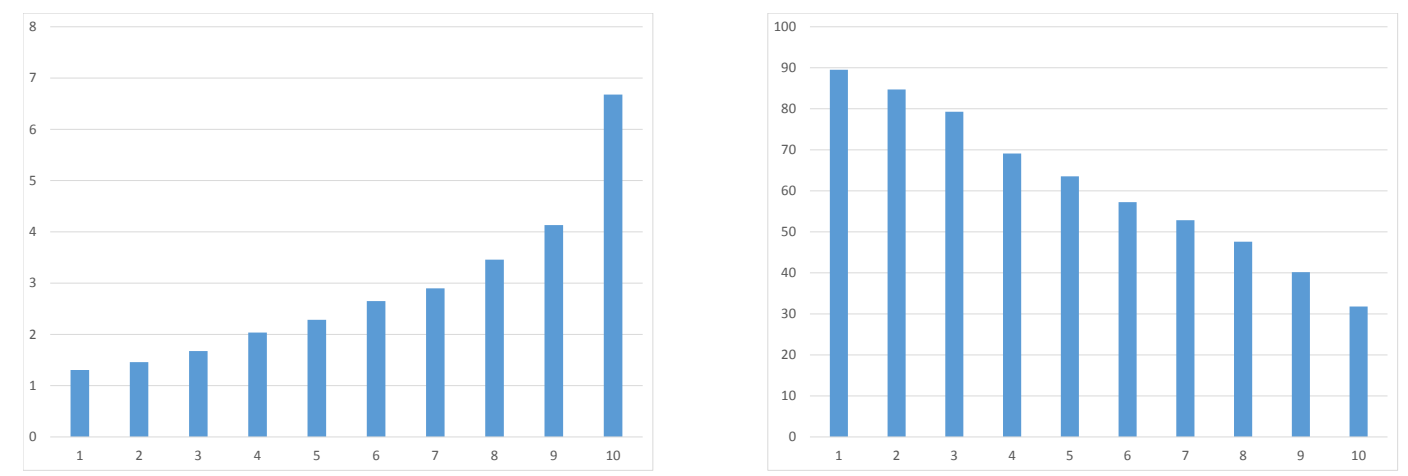

(e) NumPBsPerHF $F_{h, t}$

(f) HFCreditor $H H I_{h, t}$

Figure 4: Hedge fund characteristics by TotalHFBorrowing ${ }_{h, t}$ decile

This figure illustrates characteristics of the hedge funds sorted into TotalHFBorrowing $g_{h, t}$ deciles each quarter. The histograms show the mean value for all hedge fund-quarter observations in that decile for TotalHF Borrowing $_{h, t}, \mathrm{NAV}_{h, t}$, Leverage $_{h, t}$, PortIlliq $q_{h, t}, \mathrm{NumPBsPerHF}_{h, t}$, and HFCreditorH HI $I_{h, t}$, respectively. 


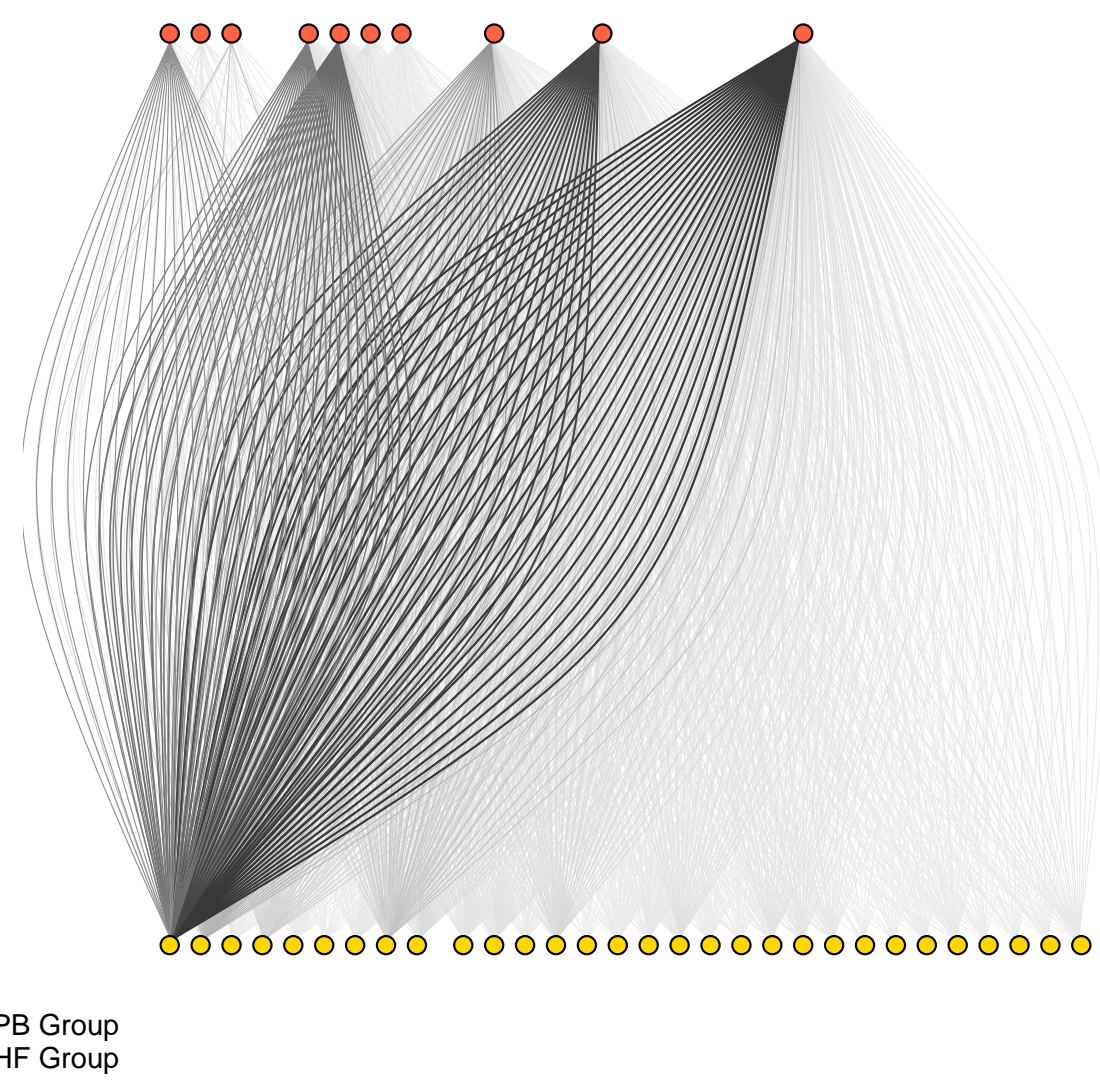

Figure 5: Hedge fund-prime broker bipartite credit network

This figure depicts the bipartite hedge fund-prime broker lending network in Q1 2017. The nodes in yellow depict 30 groups of funds, grouped according to the total amount borrowed. The nodes in red depict 10 groups of two prime brokers, grouped according to total amount lent. The depth of color of an edge denotes the amount of credit between the groups connected by that edge. 

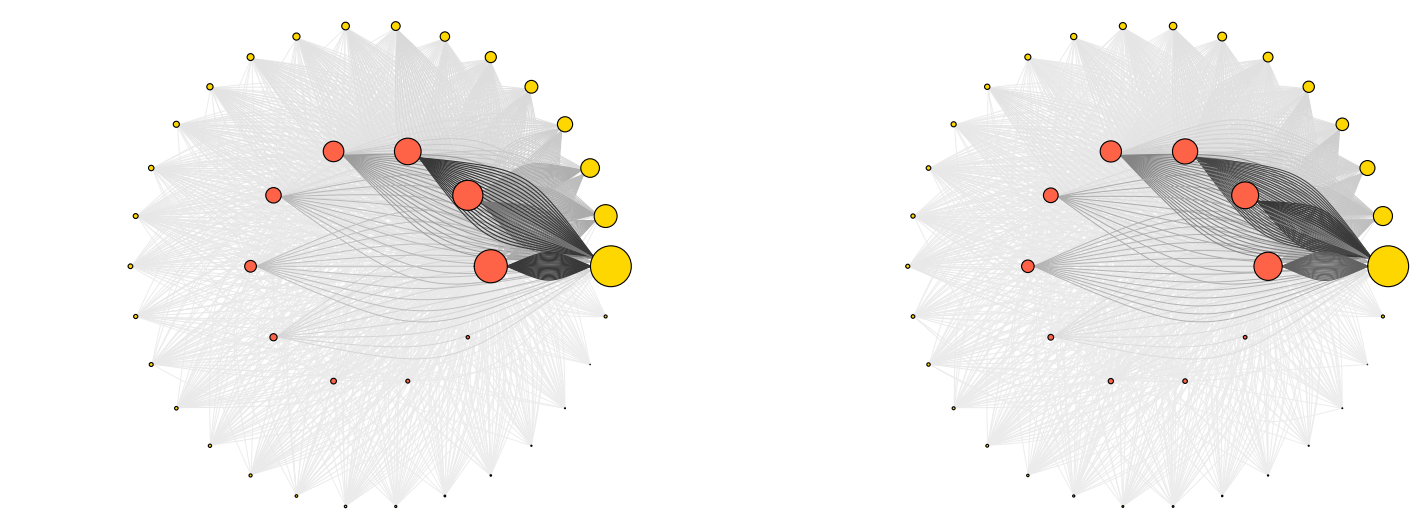

(a) Q1 2014

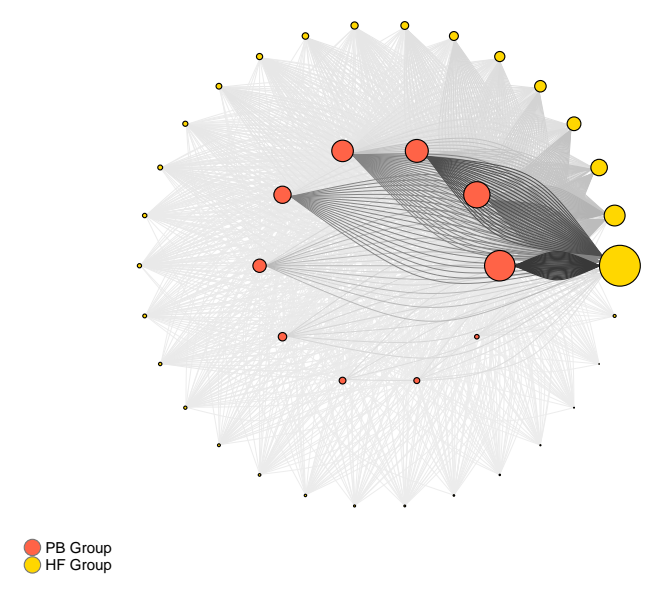

PB Group
HF Group

(a) Q1 2014

(c) Q1 2016 (b) Q1 2015

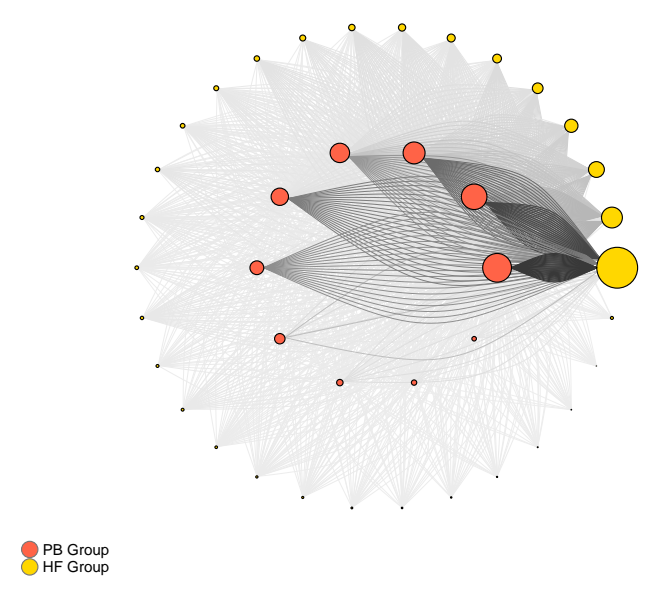

(d) Q1 2017

Figure 6: Hedge fund-prime broker network through time

These figures depict snapshots of the hedge fund-prime broker lending network at four points in time: Q1 2014, Q1 2015, Q1 2016, and Q1 2017. The nodes in yellow depict 30 groups of funds, grouped according to the total amount borrowed. The nodes in red depict 10 groups of two prime brokers, grouped according to total amount lent. The depth of color of an edge denotes the amount of credit between the groups connected by that edge. The relative sizes of the vertices represent the total amount of credit extended or received by that node. 


\section{Table 1: Summary statistics}

This table shows the summary statistics for the main variables used in the analysis. The variables are at a quarterly frequency and are over the period from 2012:Q4 to 2017:Q1. Subscript $h$ refers to a hedge fund, $p$ to a prime broker, and $t$ to a quarter. Returns, flows, alphas, and fractional variables are in percent. PortIlliq $q_{h, t}$, ShareRes $_{h, t}$, and FinDur ${ }_{h, t}$ are in calendar days. $N A V_{h, t}$, TotalHFBorrowing ${ }_{h, t}$, PBMktCap,$t$, TotalPBLending ${ }_{p, t}$, and $H F_{-} P B_{-}$Credit $_{h, p, t}$ are in US dollar millions. The $N$ column shows the number of observations used to calculate the statistics in a particular row. The last four columns show percentiles.

\begin{tabular}{|c|c|c|c|c|c|c|c|c|}
\hline & $\mathrm{N}$ & Mean & Median & St. Dev. & $25^{t h}$ & $75^{t h}$ & $10^{t h}$ & $90^{t h}$ \\
\hline \multicolumn{9}{|c|}{ Panel A: Hedge fund characteristics } \\
\hline HFReturn $_{h, t}$ & 8,668 & 1.721 & 1.790 & 5.402 & -0.650 & 4.190 & -3.890 & 7.440 \\
\hline HFFlows $s_{h, t}$ & 8,351 & -0.481 & -0.160 & 8.995 & -4.358 & 2.637 & -11.810 & 10.566 \\
\hline$N A V_{h, t}$ & 9,528 & $1,973.699$ & $1,029.741$ & $3,031.078$ & 528.940 & $2,101.801$ & 229.463 & $4,559.079$ \\
\hline PortIlliq $_{h, t}$ & 9,440 & 35.521 & 12.615 & 64.252 & 4.209 & 36.023 & 1.271 & 80.738 \\
\hline ShareRes $_{h, t}$ & 9,523 & 168.880 & 158.160 & 110.844 & 60.500 & 258.385 & 19.000 & 336.467 \\
\hline FinDur $_{h, t}$ & 9,471 & 43.395 & 3.500 & 75.041 & 0.500 & 59.900 & 0.500 & 134.000 \\
\hline MgrStake $_{h, t}$ & 9,528 & 15.496 & 6.000 & 25.084 & 1.000 & 15.000 & 0.000 & 49.000 \\
\hline SecOTCShare $_{h, t}$ & 9,027 & 37.837 & 17.000 & 40.631 & 0.000 & 83.000 & 0.000 & 100.000 \\
\hline alpha $_{h, t}$ & 8,536 & 0.556 & 0.536 & 2.218 & -0.204 & 1.211 & -1.141 & 1.992 \\
\hline alpha_delev $v_{h, t}$ & 8,536 & 0.358 & 0.277 & 1.745 & -0.115 & 0.724 & -0.703 & 1.269 \\
\hline TotalHF Borrowing $_{h, t}$ & 9,528 & $2,147.972$ & 472.701 & $8,910.788$ & 152.808 & $1,396.189$ & 60.403 & $4,317.286$ \\
\hline$G A V_{h, t} / N A V_{h, t}\left(\right.$ Leverage $\left._{h, t}\right)$ & 9,528 & 2.216 & 1.553 & 2.885 & 1.285 & 2.148 & 1.128 & 3.220 \\
\hline NumPBsPerH $F_{h, t}$ & 9,528 & 2.862 & 2.000 & 2.485 & 1.000 & 4.000 & 1.000 & 6.000 \\
\hline$H F C r e d i t o r H H I_{h, t}$ & 9,528 & 61.535 & 52.818 & 30.877 & 34.382 & 100.000 & 22.860 & 100.000 \\
\hline
\end{tabular}

Panel B: Prime broker characteristics

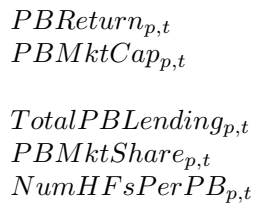

PBReturn $_{p, t}$

PBMktCap,$t$

TotalPBLending $g_{p, t}$

PBMktShare ${ }_{p, t}$

NumHFsPerPB $B_{p, t}$

Panel C: Credit exposures

\begin{tabular}{|c|c|c|c|c|c|c|c|c|}
\hline$H F_{-} P B_{-} C r e d i t_{h, p, t}$ & 26,748 & 753.812 & 256.633 & $2,020.733$ & 101.937 & 682.624 & 44.975 & $1,572.570$ \\
\hline$\frac{H F_{-} P B_{-} C r e d i t_{h, p, t}}{H F_{-} N A V_{h, t}}$ & 26,748 & 34.422 & 17.086 & 69.740 & 9.531 & 34.540 & 6.440 & 73.592 \\
\hline 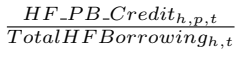 & 26,748 & 30.988 & 21.497 & 27.469 & 10.767 & 42.090 & 5.360 & 78.313 \\
\hline$P B R a n k I n H F_{h, p, t}$ & 26,748 & 0.678 & 0.667 & 0.292 & 0.455 & 1.000 & 0.250 & 1.000 \\
\hline 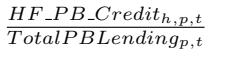 & 26,748 & 2.236 & 0.310 & 8.406 & 0.109 & 1.047 & 0.044 & 3.558 \\
\hline$H F \operatorname{RankInP} B_{h, p, t}$ & 26,748 & 0.511 & 0.509 & 0.290 & 0.260 & 0.761 & 0.110 & 0.914 \\
\hline
\end{tabular}




\section{Table 2: Hedge fund characteristics by strategy}

This table shows the summary statistics of hedge fund characteristics related to size, borrowing, and OTC trading broken down by hedge fund investment strategy. The variables are at a quarterly frequency and are over the period from 2012:Q4 to 2017:Q1. $N A V_{h, t}$ and TotalHFBorrowing $g_{h, t}$ are in US dollar millions. Leverage $_{h, t}$ is a ratio. HFCreditor HHI $I_{h, t}$ is defined in (2). SecOTCShare $e_{h, t}$ is in percent. The $N$ columns show the number of hedge fund-quarter observations used to calculate the statistics on a particular variable.

\begin{tabular}{|c|c|c|c|c|c|c|c|c|}
\hline & $\mathrm{N}$ & Mean & Median & Stdev & $\mathrm{N}$ & Mean & Median & Stdev \\
\hline & \multicolumn{4}{|c|}{$N A V_{h, t}$} & \multicolumn{4}{|c|}{ TotalHF Borrowing ${ }_{h, t}$} \\
\hline Credit & 460 & $1,023.577$ & 733.624 & 986.920 & 460 & 377.701 & 216.583 & 540.258 \\
\hline Equity & 3,947 & $1,732.983$ & 983.016 & $2,678.711$ & 3,947 & $1,512.599$ & 444.525 & $3,273.897$ \\
\hline Event Driven & 961 & $1,671.599$ & $1,073.834$ & $1,690.706$ & 961 & 680.781 & 295.788 & $1,087.061$ \\
\hline Macro & 410 & $3,013.777$ & $1,403.380$ & $4,606.354$ & 410 & $3,241.623$ & $1,165.662$ & $4,929.954$ \\
\hline Multi-strategy & 2,197 & $3,008.643$ & $1,422.686$ & $4,232.034$ & 2,197 & $4,146.667$ & 709.144 & $15,986.894$ \\
\hline Relative Value & 889 & $1,099.171$ & 745.579 & $1,249.338$ & 889 & $2,727.786$ & 545.937 & $11,599.162$ \\
\hline \multirow[t]{2}{*}{ Other } & 596 & $1,521.432$ & 995.871 & $1,689.848$ & 596 & $1,262.845$ & 448.173 & $3,404.619$ \\
\hline & \multicolumn{4}{|c|}{ NumPBsPerH $F_{h, t}$} & \multicolumn{4}{|c|}{ Leverage $_{h, t}$} \\
\hline Credit & 460 & 2.393 & 2.000 & 31.912 & 460 & 1.790 & 1.549 & 1.749 \\
\hline Equity & 3947 & 2.580 & 2.000 & 29.555 & 3947 & 1.725 & 1.503 & 0.883 \\
\hline Event Driven & 961 & 1.626 & 1.000 & 26.702 & 961 & 1.643 & 1.309 & 1.185 \\
\hline Macro & 410 & 4.202 & 3.000 & 33.181 & 410 & 4.284 & 2.493 & 4.769 \\
\hline Multi-strategy & 2197 & 3.237 & 3.000 & 30.546 & 2197 & 2.173 & 1.713 & 1.540 \\
\hline Relative Value & 889 & 4.256 & 3.000 & 28.942 & 889 & 4.581 & 2.103 & 7.469 \\
\hline \multirow[t]{2}{*}{ Other } & 596 & 2.851 & 2.000 & 32.420 & 596 & 2.010 & 1.608 & 1.445 \\
\hline & \multicolumn{4}{|c|}{$H F C$ reditor $H H I_{h, t}$} & \multicolumn{4}{|c|}{ SecOTCShare $_{h, t}$} \\
\hline Credit & 460 & 69.487 & 70.629 & 1.939 & 448 & 80.266 & 97.000 & 31.153 \\
\hline Equity & 3947 & 61.040 & 52.518 & 1.789 & 3613 & 5.993 & 0.000 & 14.276 \\
\hline Event Driven & 961 & 79.646 & 100.000 & 0.968 & 934 & 43.317 & 37.000 & 36.559 \\
\hline Macro & 410 & 55.874 & 49.262 & 3.693 & 408 & 74.850 & 94.000 & 34.616 \\
\hline Multi-strategy & 2197 & 57.513 & 50.390 & 2.696 & 2181 & 43.936 & 41.000 & 34.750 \\
\hline Relative Value & 889 & 48.406 & 40.835 & 3.744 & 876 & 83.908 & 100.000 & 28.768 \\
\hline Other & 596 & 65.453 & 57.291 & 2.838 & 504 & 76.411 & 100.000 & 38.021 \\
\hline
\end{tabular}




\section{Table 3: Prime broker shocks and changes to hedge fund lending}

This table reports the coefficient estimates and $t$-statistics of the panel regression model given in equations (5) and (6). The dependent variable is $\Delta \log H F_{-} P B_{-} C_{r e d i t}, p, t$. The data are quarterly from 2012:Q4 to 2017:Q1. Fund, time, prime broker, strategy, and fund $\times$ time fixed effects are used where indicated. The standard errors are clustered at the prime broker-quarter level. The independent variables, with the exception of the PBSHOCK, are standardized. The significance of the coefficient estimate is indicated by ${ }^{*}$ for $p<0.10,{ }^{* *}$ for $p<0.05$, and ${ }^{* * *}$ for $p<0.01$.

\begin{tabular}{|c|c|c|c|c|c|c|c|c|}
\hline & $(1)$ & $(2)$ & $(3)$ & $(4)$ & $(5)$ & (6) & $(7)$ & $(8)$ \\
\hline$P B S H O C K_{h, p, t}$ & $\begin{array}{r}-11.165^{* * *} \\
-3.516\end{array}$ & $\begin{array}{r}-12.110^{* * *} \\
-3.350\end{array}$ & $\begin{array}{r}-10.636^{* * *} \\
-3.085\end{array}$ & $\begin{array}{r}-10.735^{* *} \\
-2.482\end{array}$ & $\begin{array}{r}-14.398^{* * *} \\
-4.875\end{array}$ & $\begin{array}{r}-12.886^{* * *} \\
-3.723\end{array}$ & $\begin{array}{r}-9.906^{* * *} \\
-3.480\end{array}$ & $\begin{array}{r}-10.626^{* * *} \\
-3.064\end{array}$ \\
\hline$P B R a n k I n H F_{h, p, t-1}$ & & & & & $\begin{array}{l}-0.717 \\
-1.009\end{array}$ & $\begin{array}{l}-0.286 \\
-0.404\end{array}$ & $\begin{array}{r}-4.816^{* * *} \\
-7.604\end{array}$ & $\begin{array}{r}-5.035^{* * *} \\
-7.779\end{array}$ \\
\hline$H F \operatorname{RankInP} B_{h, p, t-1}$ & & & & & $\begin{array}{r}-22.636^{* * *} \\
-15.972\end{array}$ & $\begin{array}{r}-24.909^{* * *} \\
-17.426\end{array}$ & $\begin{array}{r}-10.987^{* * *} \\
-12.967\end{array}$ & $\begin{array}{r}-11.310^{* * *} \\
-13.079\end{array}$ \\
\hline SecOTCShare $_{h, t-1}$ & & & & & $\begin{array}{l}1.457 \\
0.629\end{array}$ & $\begin{array}{l}1.556 \\
0.676\end{array}$ & $\begin{array}{l}-1.113 \\
-1.282\end{array}$ & $\begin{array}{l}-1.312 \\
-1.501\end{array}$ \\
\hline HF Return $_{h, t-1}$ & & & & & $\begin{array}{l}0.832 \\
1.435\end{array}$ & $\begin{array}{l}0.840 \\
1.457\end{array}$ & $\begin{array}{r}2.531^{* * *} \\
5.120\end{array}$ & $\begin{array}{r}2.546^{* * *} \\
5.161\end{array}$ \\
\hline HFFlows $_{h, t-1}$ & & & & & $\begin{array}{r}3.345^{* * *} \\
5.991\end{array}$ & $\begin{array}{r}3.360^{\text {*** }} \\
6.031\end{array}$ & $\begin{array}{r}6.468^{* * *} \\
13.179\end{array}$ & $\begin{array}{r}6.491^{* * *} \\
13.153\end{array}$ \\
\hline $\log N A V_{h, t-1}$ & & & & & $\begin{array}{r}15.082^{* * *} \\
5.917\end{array}$ & $\begin{array}{r}16.820^{* * *} \\
6.605\end{array}$ & $\begin{array}{r}8.243^{* * *} \\
10.955\end{array}$ & $\begin{array}{r}8.664^{* * *} \\
11.295\end{array}$ \\
\hline PortIlliq $_{h, t-1}$ & & & & & $\begin{array}{l}-2.488 \\
-1.563\end{array}$ & $\begin{array}{r}-2.872^{*} \\
-1.828\end{array}$ & $\begin{array}{l}-0.799 \\
-1.618\end{array}$ & $\begin{array}{r}-0.956^{* *} \\
-1.998\end{array}$ \\
\hline$H F C$ reditor $H H I_{h, t-1}$ & & & & & $\begin{array}{r}6.361^{* * *} \\
5.594\end{array}$ & $\begin{array}{r}6.083^{* * *} \\
5.388\end{array}$ & $\begin{array}{r}4.019^{* * *} \\
7.378\end{array}$ & $\begin{array}{r}3.909^{* * *} \\
7.076\end{array}$ \\
\hline IsPBCustodian $_{h, p, t-1}$ & & & & & $\begin{array}{r}4.084^{* * *} \\
4.206\end{array}$ & $\begin{array}{r}3.507^{* * *} \\
3.485\end{array}$ & $\begin{array}{r}3.067^{* * *} \\
4.129\end{array}$ & $\begin{array}{r}2.607^{\text {*** }} \\
3.470\end{array}$ \\
\hline $\begin{array}{l}\text { Observations } \\
\text { Adjusted } \mathrm{R}^{2}\end{array}$ & $\begin{array}{c}13,576 \\
0.045\end{array}$ & $\begin{array}{c}13,576 \\
0.047\end{array}$ & $\begin{array}{c}13,576 \\
0.015\end{array}$ & $\begin{array}{c}13,576 \\
0.163\end{array}$ & $\begin{array}{c}13,576 \\
0.110\end{array}$ & $\begin{array}{c}13,576 \\
0.117\end{array}$ & $\begin{array}{c}13,576 \\
0.072\end{array}$ & $\begin{array}{c}13,576 \\
0.076\end{array}$ \\
\hline Other Controls & No & No & No & No & Yes & Yes & Yes & Yes \\
\hline Fund FE & Yes & Yes & No & No & Yes & Yes & No & No \\
\hline Quarter FE & Yes & Yes & Yes & No & Yes & Yes & Yes & Yes \\
\hline Prime Broker FE & No & Yes & Yes & Yes & No & Yes & No & Yes \\
\hline Strategy FE & No & No & Yes & No & No & No & Yes & Yes \\
\hline Fund $\times$ Quarter FE & No & No & No & Yes & No & No & No & No \\
\hline
\end{tabular}




\section{Table 4: Prime broker lending versus hedge fund borrowing channel}

This table reports the coefficient estimates and $t$-statistics of the panel regression model given in equation (7). The dependent variable is $\Delta \log H F_{-} P B_{-} C_{r e d i t}, p, t$. The data are quarterly from 2012:Q4 to 2017:Q1. The specifications include fund, time, and prime broker fixed effects. The standard errors are clustered at the prime broker-quarter level. The independent variables, with the exception of PBSHOCK, are standardized. The significance of the coefficient estimate is indicated by * for $p<0.10,{ }^{* *}$ for $p<0.05$, and ${ }^{* * *}$ for $p<$ 0.01 .

\begin{tabular}{|c|c|c|c|c|c|c|}
\hline & (1) & (2) & (3) & (4) & (5) & (6) \\
\hline$P B S H O C K_{h, p, t}$ & $\begin{array}{l}-12.084^{* * *} \\
-3.398\end{array}$ & $\begin{array}{l}-12.384^{* * *} \\
-3.471\end{array}$ & $\begin{array}{l}-11.577^{* * *} \\
-3.078\end{array}$ & $\begin{array}{l}-10.924^{* * *} \\
-2.962\end{array}$ & $\begin{array}{l}-10.923^{* * *} \\
-2.962\end{array}$ & $\begin{array}{c}-12.384^{* * * *} \\
-3.471\end{array}$ \\
\hline NumPBsPerH $F_{h, t-1}$ & $\begin{array}{c}-7.314^{* * *} \\
-3.280\end{array}$ & & & & & \\
\hline $\mathrm{PBSHOCK}_{h, p, t} \times$ NumPBsPerHF$F_{h, t-1}$ & $\begin{array}{l}-1.196 \\
-0.277\end{array}$ & & & & & \\
\hline $\log N A V_{h, t-1}$ & & $\begin{array}{l}1.867 \\
0.760\end{array}$ & & & & \\
\hline$P B S H O C K_{h, p, t} \times \log N A V_{h, t-1}$ & & $\begin{array}{l}1.927 \\
1.102\end{array}$ & & & & \\
\hline HF Return $_{h, t-1}$ & & & $\begin{array}{l}0.683 \\
1.158\end{array}$ & & & \\
\hline PBSHOCK $_{h, p, t} \times$ HFReturn $_{h, t-1}$ & & & $\begin{array}{l}3.712 \\
1.377\end{array}$ & & & \\
\hline SecOTCShare $_{h, t-1}$ & & & & $\begin{array}{l}0.499 \\
0.205\end{array}$ & & \\
\hline PBSHOCK $K_{h, p, t} \times$ SecOTCShare $_{h, t-1}$ & & & & $\begin{array}{l}5.908^{* *} \\
2.088\end{array}$ & & \\
\hline PBRankInH $F_{h, p, t-1}$ & & & & & $\begin{array}{l}-8.673^{* * *} \\
-15.207\end{array}$ & \\
\hline$P B S H O C K_{h, p, t} \times P B R a n k I n H F_{h, p, t-1}$ & & & & & $\begin{array}{l}0.890 \\
0.270\end{array}$ & \\
\hline PctRehypothecable $e_{h, t-1}$ & & & & & & $\begin{array}{c}-7.073^{* * *} \\
-4.542\end{array}$ \\
\hline PBSHOCK $_{h, p, t} \times$ PctRehypothecable $_{h, t-1}$ & & & & & & $\begin{array}{c}6.885^{* * *} \\
2.605\end{array}$ \\
\hline $\begin{array}{l}\text { Observations } \\
\text { Adjusted } \mathrm{R}^{2}\end{array}$ & $\begin{array}{c}13,576 \\
0.049\end{array}$ & $\begin{array}{c}13,576 \\
0.047\end{array}$ & $\begin{array}{c}13,576 \\
0.047\end{array}$ & $\begin{array}{c}13,576 \\
0.047\end{array}$ & $\begin{array}{c}13,576 \\
0.073\end{array}$ & $\begin{array}{l}9,870 \\
0.040\end{array}$ \\
\hline Fund FE & Yes & Yes & Yes & Yes & Yes & Yes \\
\hline Quarter FE & Yes & Yes & Yes & Yes & Yes & Yes \\
\hline Prime Broker FE & Yes & Yes & Yes & Yes & Yes & Yes \\
\hline
\end{tabular}




\section{Table 5: Prime broker shocks and lending relationships: the extensive margin}

This table shows the changes to the number of hedge fund lending relationships when a prime broker suffers a liquidity shock. The reported coefficient estimates and $t$-statistics are for the panel regression model given in equation (8). In columns 1-3, the dependent variable is $\Delta N u m H F s P e r P B_{p, t}$. In column 4 , the dependent variable is the percentage change in $N u m H F s P e r P B_{p, t}$. The data are quarterly from 2012:Q4 to 2017:Q1. The specifications include quarter and prime broker fixed effects where indicated. The standard errors are clustered at the quarter level. The independent variables, with the exception of PBSHOCK, are standardized. $t$-statistics are shown below the corresponding coefficient estimates. The significance of the coefficient estimate is indicated by ${ }^{*}$ for $p<0.10,{ }^{* *}$ for $p<0.05$, and $* * *$ for $p<0.01$.

\begin{tabular}{|c|c|c|c|c|}
\hline & \multicolumn{3}{|c|}{ Chg } & \multirow{2}{*}{$\begin{array}{c}\% \text { Chg } \\
(4)\end{array}$} \\
\hline & $(1)$ & $(2)$ & $(3)$ & \\
\hline$P B S H O C K_{p, t}$ & $\begin{array}{r}-6.729^{* * *} \\
-11.641\end{array}$ & $\begin{array}{r}-7.881^{* * *} \\
-9.295\end{array}$ & $\begin{array}{r}-6.095^{* * *} \\
-8.164\end{array}$ & $\begin{array}{r}-13.361^{* * *} \\
-3.943\end{array}$ \\
\hline PBReturn $_{p, t-1}$ & & & $\begin{array}{l}0.031 \\
0.900\end{array}$ & $\begin{array}{r}0.413^{* *} \\
2.454\end{array}$ \\
\hline $\operatorname{LogPBMktCap_{p,t-1}}$ & & & $\begin{array}{l}0.399 \\
1.421\end{array}$ & $\begin{array}{r}-9.868^{* * *} \\
-2.740\end{array}$ \\
\hline $\begin{array}{l}\text { Observations } \\
\text { Adjusted } \mathrm{R}^{2}\end{array}$ & $\begin{array}{c}382 \\
0.096\end{array}$ & $\begin{array}{c}382 \\
0.072\end{array}$ & $\begin{array}{c}382 \\
0.096\end{array}$ & $\begin{array}{c}382 \\
0.043\end{array}$ \\
\hline $\begin{array}{l}\text { Quarter FE } \\
\text { Prime Broker FE }\end{array}$ & $\begin{array}{l}\text { Yes } \\
\text { No }\end{array}$ & $\begin{array}{l}\text { Yes } \\
\text { Yes }\end{array}$ & $\begin{array}{l}\text { Yes } \\
\text { No }\end{array}$ & $\begin{array}{l}\text { Yes } \\
\text { No }\end{array}$ \\
\hline
\end{tabular}




\section{Table 6: Prime broker shock impact on aggregate hedge fund borrowing}

This table reports the coefficient estimates and $t$-statistics of the panel regression model given in equation (9). The dependent variable is $\Delta \log$ TotalHF Borrowing,$t$. The data are quarterly from 2012:Q4 to 2017:Q1. The specifications include fund and quarter fixed effects. The standard errors are clustered at the quarter level. The independent variables, with the exception of ShockExposure, are standardized. The significance of the coefficient estimate is indicated by ${ }^{*}$ for $p<0.10$, ** for $p<0.05$, and $* * *$ for $p<0.01$.

\begin{tabular}{|c|c|c|c|c|c|c|}
\hline & $(1)$ & $(2)$ & $(3)$ & $(4)$ & $(5)$ & $(6)$ \\
\hline ShockExposure $_{h, t-1}$ & $\begin{array}{r}-4.713^{* *} \\
-2.284\end{array}$ & $\begin{array}{r}-3.441^{*} \\
-1.873\end{array}$ & $\begin{array}{r}-7.331^{* * *} \\
-3.551\end{array}$ & $\begin{array}{r}-3.719^{*} \\
-1.680\end{array}$ & $\begin{array}{r}-4.519^{* *} \\
-2.229\end{array}$ & $\begin{array}{r}-4.279^{* *} \\
-2.043\end{array}$ \\
\hline NumPBsPer $H F_{h, t-1}$ & & $\begin{array}{r}-21.411^{* * *} \\
-5.203\end{array}$ & & & & $\begin{array}{r}-21.180^{* * *} \\
-5.058\end{array}$ \\
\hline ShockExposure $_{h, t-1} \times N u m P B s P e r H F_{h, t-1}$ & & $\begin{array}{r}6.920^{* * *} \\
2.741\end{array}$ & & & & $\begin{array}{r}7.692^{\text {**** }} \\
3.026\end{array}$ \\
\hline $\log N A V_{h, t-1}$ & & & $\begin{array}{l}-0.016 \\
-0.004\end{array}$ & & & $\begin{array}{l}1.148 \\
0.276\end{array}$ \\
\hline ShockExposure $_{h, t-1} \times \log N A V_{h, t-1}$ & & & $\begin{array}{r}5.724^{* * *} \\
3.413\end{array}$ & & & $\begin{array}{r}2.918^{* *} \\
2.103\end{array}$ \\
\hline HF Return $_{h, t-1}$ & & & & $\begin{array}{l}1.423 \\
1.409\end{array}$ & & $\begin{array}{l}1.046 \\
1.041\end{array}$ \\
\hline ShockExposure $_{h, t-1} \times$ HFReturn $_{h, t-1}$ & & & & $\begin{array}{r}5.323^{* *} \\
2.500\end{array}$ & & $\begin{array}{r}6.005^{* * *} \\
2.943\end{array}$ \\
\hline SecOTCShare $_{h, t-1}$ & & & & & $\begin{array}{l}1.820 \\
0.481\end{array}$ & $\begin{array}{l}3.375 \\
0.901\end{array}$ \\
\hline ShockExposure $_{h, t-1} \times$ SecOTCShare $_{h, t-1}$ & & & & & $\begin{array}{r}-6.028^{* * *} \\
-3.367\end{array}$ & $\begin{array}{r}-4.980^{* *} \\
-2.423\end{array}$ \\
\hline $\begin{array}{l}\text { Observations } \\
\text { Adjusted } \mathrm{R}^{2}\end{array}$ & $\begin{array}{l}2,917 \\
0.010\end{array}$ & $\begin{array}{l}2,917 \\
0.070\end{array}$ & $\begin{array}{l}2,917 \\
0.012\end{array}$ & $\begin{array}{l}2,917 \\
0.013\end{array}$ & $\begin{array}{l}2,917 \\
0.011\end{array}$ & $\begin{array}{l}2,917 \\
0.074\end{array}$ \\
\hline $\begin{array}{l}\text { Fund FE } \\
\text { Quarter FE }\end{array}$ & $\begin{array}{l}\text { Yes } \\
\text { Yes }\end{array}$ & $\begin{array}{l}\text { Yes } \\
\text { Yes }\end{array}$ & $\begin{array}{l}\text { Yes } \\
\text { Yes }\end{array}$ & $\begin{array}{l}\text { Yes } \\
\text { Yes }\end{array}$ & $\begin{array}{l}\text { Yes } \\
\text { Yes }\end{array}$ & $\begin{array}{l}\text { Yes } \\
\text { Yes }\end{array}$ \\
\hline
\end{tabular}




\section{Appendix A Data appendix}

\section{A.1 Constructing the prime broker and counterparty data sample}

The initial steps for processing the Form PF data and merging with the Form ADV data are similar to those described in Kruttli, Monin, and Watugala (2019). In this paper, we use Form PF filings for qualifying hedge funds (QHFs) from 2012Q4 to 2017Q1. The methodology used to expand the dataset with information on hedge funds and their creditors is as follows.

Question 47 (Q47) of Form PF requires qualifying hedge funds to report the name and amount borrowed for each of its creditors from whom it borrows an amount equal to or in excess of $5 \%$ of its NAV. The form contains a set of choices of 30 well-known brokers that the fund can choose as its creditors. These are generally the names of parent companies, e.g. JPMorgan or Goldman Sachs, not the legal names of specific affiliates or subsidiaries. The menu also gives an "Other" option. If the fund selects "Other" then it manually inputs the creditor's name in an associated description field. We process this Other description field to ensure consistency of creditor names. Where possible, we map the descriptions to their parent companies. We obtain the list of a fund's prime brokers from Form ADV. These prime broker names are similarly cleaned and mapped to their parent companies to ensure consistency.

Large Hedge Fund Advisers report on their Qualifying Hedge Funds to Form PF on a quarterly basis. These advisers report to Form ADV on an annual basis. Form PF and Form ADV data are merged such that data for a given fund-date pair on Form PF is associated to the latest Form ADV data available as of that date.

Form PF data are naturally a fund-date panel. Adding Q47 data lets us create a fundcreditor-date panel. Any fund in the fund-creditor-date panel must have nonzero borrowing, specifically must have at least one creditor from whom it borrows an amount equal to or in excess of $5 \%$ of its NAV. We use the prime broker information from Form ADV to flag 
whether a creditor is also a prime broker in the fund-creditor-date panel. We consider a given fund creditor to be of the "prime broker type" if it appears as a listed prime broker on Form ADV for any fund at any point in our sample. For consistency, we require that the sum of Q47 borrowing from significant creditors be less than or equal to the total overall fund borrowing (reported in Form PF, Q43). This removes 515 fund-creditor-date observations from our sample.

Table A.1 shows the extent to which the borrowing listed in Q47 and Q43 are from a hedge fund's prime brokers. The median value for all four ratios is over $90 \%$, indicating that most of a hedge fund's borrowing is from the prime broker set. Table A.2 summarizes the type of credit agreements under which the hedge funds conduct their borrowing. Table A.3 reports summary statistics for the type of collateral used by hedge funds in their borrowing as a percentage of the total secured borrowing from prime brokers. Table A.4 shows the number of nodes and total amount of credit in the hedge fund-prime broker network at each quarter.

\section{Table A.1: Borrowing from prime brokers and significant creditors}

This table shows the extent to which borrowing from significant creditors (Form PF, Question 47), some of whom are also prime brokers, account for the total overall borrowing by a hedge fund (Form PF, Question $43)$.

\begin{tabular}{lrrrrrr}
\hline & $\mathrm{N}$ & Mean & Median & Std. Dev. & $25 \%$ & $75 \%$ \\
\hline \% major creditors who are also prime brokers & 9,612 & 77.048 & 100.000 & 37.368 & 50.000 & 100.000 \\
\% total prime broker borrowing to total major creditor borrowing & 9,612 & 78.572 & 100.000 & 36.972 & 72.131 & 100.000 \\
& & & & & & \\
& 9,612 & 87.353 & 97.554 & 20.066 & 84.050 & 100.000 \\
\% total major creditor borrowing to total fund borrowing & 9,612 & 69.599 & 90.244 & 36.971 & 40.255 & 99.989 \\
\hline \% total prime broker borrowing to total fund borrowing &
\end{tabular}




\section{Table A.2: Type of borrowing}

This table shows the summary statistics on the fraction of borrowing conducted via prime broker agreements and the fraction conducted via repo agreements.

\begin{tabular}{|c|c|c|c|c|c|c|c|c|}
\hline & $\mathrm{N}$ & Mean & Median & St. Dev. & $25^{t h}$ & $75^{t h}$ & $10^{t h}$ & $90^{t h}$ \\
\hline$\frac{\text { PrimeBrokerBorrowing } g_{h, t}}{\text { TotalHFBorrowing }}$ & 9,528 & 74.682 & 100.000 & 39.374 & 53.191 & 100.000 & 0 & 100 \\
\hline$\frac{\text { RepoBorrowing }_{h, t}}{\text { TotalHF Forrowing } g_{h, t}}$ & 9,528 & 18.247 & 0.000 & 34.139 & 0.000 & 15.031 & 0 & 95.86869 \\
\hline
\end{tabular}

\section{Table A.3: Collateral used for secured borrowing from prime brokers}

This table reports the summary statistics on the type of collateral used by hedge funds in their borrowing as a percentage of the total secured borrowing from prime brokers and the extent to which the collateral could be rehypothecated.

\begin{tabular}{|c|c|c|c|c|c|c|}
\hline & $\mathrm{N}$ & Mean & Median & St. Dev. & $25^{t h}$ & $75^{\text {th }}$ \\
\hline$\frac{\text { CashCollateral }_{h, t}}{\text { TotalHFBorrowing } \text { in }_{h, t}}$ & 9,528 & 52.402 & 41.758 & 69.933 & 2.983 & 86.725 \\
\hline$\frac{\text { SecCollateral }_{h, t}}{\text { TotalHFBorrowing }}$ & 9,528 & 111.500 & 85.759 & 152.660 & 28.417 & 137.346 \\
\hline$\frac{\text { TotalCollateral }}{h, t}$ & 9,528 & 168.204 & 119.948 & 178.664 & 100.000 & 179.658 \\
\hline$\frac{\text { RehypothecableCollateral }}{h, t}$ & 9,528 & 58.686 & 83.000 & 43.849 & 1.000 & 100.000 \\
\hline$\frac{\text { RehypothecableCollateral }}{h, t}, \frac{\text { TotalHFBorrowing } g_{h, t}}{\text { Tot }}$ & 9,528 & 84.201 & 81.001 & 110.796 & 0.000 & 110.713 \\
\hline
\end{tabular}




\section{Table A.4: Number of counterparties and total credit by quarter}

This table reports quarterly totals of the number of hedge funds that report significant borrowing from any prime broker creditor, the number of prime brokers which are significant creditors of any reporting hedge fund, and the total amount of borrowing (in US\$ billions) corresponding to this hedge fund-prime broker credit network.

\begin{tabular}{|c|c|c|c|}
\hline Qtr & Num HFs & Num PBs & $\sum_{h}$ TotalHF Borrowing $_{h, t}$ (US\$ billions) \\
\hline 2012Q4 & 418 & 29 & 867.461 \\
\hline 2013Q1 & 454 & 31 & $1,017.708$ \\
\hline 2013Q2 & 486 & 34 & $1,002.689$ \\
\hline 2013Q3 & 500 & 32 & $1,033.924$ \\
\hline 2013Q4 & 509 & 33 & $1,009.126$ \\
\hline 2014Q1 & 522 & 33 & $1,075.879$ \\
\hline 2014Q2 & 533 & 32 & $1,121.795$ \\
\hline 2014Q3 & 541 & 33 & $1,106.579$ \\
\hline 2014Q4 & 564 & 32 & $1,193.873$ \\
\hline 2015Q1 & 554 & 33 & $1,224.617$ \\
\hline 2015Q2 & 602 & 33 & $1,232.839$ \\
\hline 2015Q3 & 556 & 34 & $1,166.620$ \\
\hline 2015Q4 & 578 & 34 & $1,122.234$ \\
\hline 2016Q1 & 558 & 33 & $1,083.191$ \\
\hline 2016Q2 & 534 & 37 & $1,159.565$ \\
\hline 2016Q3 & 548 & 35 & $1,305.912$ \\
\hline 2016Q4 & 541 & 34 & $1,104.932$ \\
\hline 2017Q1 & 530 & 36 & $1,337.816$ \\
\hline
\end{tabular}




\section{Table A.5: Variable Definitions}

This table presents definitions of the main variables used in this paper. The first column gives the variable name. The second column includes a short description. The last column gives the reference to the raw data source in Form PF (https://www.sec.gov/about/forms/formpf.pdf) or Form ADV (https://www.sec.gov/about/forms/formadv.pdf). Detailed descriptions and summary statistics of these variables are given in section 2.2 .

\begin{tabular}{|c|c|c|}
\hline Variable Name & Description & Source \\
\hline$N A V_{h, t}$ & $\begin{array}{l}\text { Net asset value, or the amount of investor equity of } \\
\text { the fund, of hedge fund } h \text { at the end of quarter } t \text {. }\end{array}$ & PF Q9 \\
\hline Leverage $_{h, t}$ & $\begin{array}{l}\text { Balance sheet leverage, i.e. the ratio of gross asset } \\
\text { value to net asset value, of hedge fund } h \text { at the end } \\
\text { of quarter } t \text {. }\end{array}$ & PF Q8, Q9 \\
\hline$H F \_P B \_C r e d i t_{h, p, t}$ & $\begin{array}{l}\text { Amount borrowed by hedge fund } h \text { from prime } \\
\text { broker } p \text { at the end of quarter } t \text {. }\end{array}$ & PF Q47 \\
\hline TotalHF Borrowing $g_{h, t}$ & $\begin{array}{l}\text { Hedge fund } h \text { 's total borrowing from prime brokers } \\
\text { at the end of quarter } t \text {. See Eq. (1). }\end{array}$ & PF Q47 \\
\hline NumPBsPer $H F_{h, t}$ & $\begin{array}{l}\text { The number of prime brokers providing credit to } \\
\text { hedge fund } h \text { at the end of quarter } t \text {. }\end{array}$ & PF Q47 \\
\hline TotalPBLending $_{p, t}$ & $\begin{array}{l}\text { Prime broker } p \text { 's total lending to hedge funds at the } \\
\text { end of quarter } t \text {. See Eq. (3). }\end{array}$ & PF Q47 \\
\hline NumHFsPerPB $B_{p, t}$ & $\begin{array}{l}\text { The number of hedge funds borrowing from prime } \\
\text { broker } p \text { at the end of quarter } t \text {. }\end{array}$ & PF Q47 \\
\hline$H F C r e d i t o r H H I_{h, t}$ & $\begin{array}{l}\text { Creditor concentration of hedge fund } h \text { at the end } \\
\text { of quarter } t \text {. See Eq. (2). }\end{array}$ & PF Q47 \\
\hline PBMktShare $_{p, t}$ & $\begin{array}{l}\text { Prime broker } p \text { 's share of all lending to hedge funds } \\
\text { at the end of quarter } t \text {. See Eq. (4). }\end{array}$ & PF Q47 \\
\hline$H F R a n k I n P B_{h, p, t}$ & $\begin{array}{l}\text { Rank of hedge fund } h \text { based on lending by prime } \\
\text { broker } p \text { at the end of quarter } t \text {, normalized to lie } \\
\text { between } 0 \text { and } 1 \text {. }\end{array}$ & PF Q47 \\
\hline$P B R a n k I n H F_{h, p, t}$ & $\begin{array}{l}\text { Rank of prime broker } p \text { based on borrowings by } \\
\text { hedge fund } h \text { at the end of quarter } t \text {, normalized to } \\
\text { lie between } 0 \text { and } 1 .\end{array}$ & PF Q47 \\
\hline$I s P B_{h, p, t}$ & $\begin{array}{l}\text { Indicator for whether the prime broker } p \text { is in hedge } \\
\text { fund } h \text { 's set of prime brokers at the end of quarter } t \text {. }\end{array}$ & $\begin{array}{l}\text { ADV Schedule D, } \\
\text { Section 7.B.(1), Q24 }\end{array}$ \\
\hline IsPBCustodian $_{h, p, t}$ & $\begin{array}{l}\text { Indicator for whether the prime broker } p \text { is in hedge } \\
\text { fund } h \text { 's set of custodians at the end of quarter } t \text {. }\end{array}$ & $\begin{array}{l}\text { ADV Schedule D, } \\
\text { Section 7.B.(1), Q24 }\end{array}$ \\
\hline
\end{tabular}

Continued on the next page 


\section{Table A.5: Variable Definitions (Continued)}

This table presents definitions of the main variables used in this paper. The first column gives the variable name. The second column includes a short description. The last column gives the reference to the raw data source in Form PF (https://www.sec.gov/about/forms/formpf.pdf) or Form ADV (https://www.sec.gov/about/forms/formadv.pdf). Detailed descriptions and summary statistics of these variables are given in section 2.2 .

\begin{tabular}{|c|c|c|}
\hline Variable Name & Description & Source \\
\hline Strategy $y_{h, t}$ & $\begin{array}{l}\text { Investment strategy of hedge fund } h \text { in quarter } t \\
\text { (Credit, Equity, Event Driven, Macro, Relative } \\
\text { Value, Multi-strategy, or Other). See Kruttli, } \\
\text { Monin, and Watugala (2019). }\end{array}$ & PF Q20 \\
\hline HF Returns $_{h, t}$ & Net-of-fee returns of hedge fund $h$ in quarter $t$. & PF Q17 \\
\hline HFFlows $s_{h, t}$ & $\begin{array}{l}\text { Net investor flows to hedge fund } h \text { in quarter } t \\
\text { estimated according to } \\
F_{h, t}=\frac{N A V_{h, t}-N A V_{h, t-1} \times\left(1+r_{h, t}\right)}{N A V_{h, t-1}}\end{array}$ & PF Q9, Q17 \\
\hline PortIlliq $_{h, t}$ & $\begin{array}{l}\text { The weighted average time (in days) it would take } \\
\text { to liquidate hedge fund } h \text { 's portfolio at the end of } \\
\text { quarter } t \text {, assuming no fire sale discounting. }\end{array}$ & PF Q32 \\
\hline FinDur $_{h, t}$ & $\begin{array}{l}\text { The weighted average maturity (in days) of hedge } \\
\text { fund } h \text { 's borrowing at the end of quarter } t \text {. }\end{array}$ & PF Q46 \\
\hline ShareRes $_{h, t}$ & $\begin{array}{l}\text { The weighted average time (in days) it would take } \\
\text { for the investors of hedge fund } h \text { to withdraw all } \\
\text { the fund's NAV at the end of quarter } t \text {. }\end{array}$ & PF Q50 \\
\hline SecOTCShare $_{h, t}$ & $\begin{array}{l}\text { Fractions of securities traded over-the-counter } \\
\text { (OTC) of hedge fund } h \text { at the end of quarter } t \text {. }\end{array}$ & PF Q24 \\
\hline MgrStake $_{h, t}$ & $\begin{array}{l}\text { The percent of NAV of hedge fund } h \text { owned by the } \\
\text { managers or their related persons at the end of } \\
\text { quarter } t \text {. }\end{array}$ & $\begin{array}{l}\text { ADV Schedule D, } \\
\text { Section 7.B.(1), Q14 }\end{array}$ \\
\hline
\end{tabular}

